\title{
Well-defined Phosphonated Homo- and Copolymers via Direct Ring Opening Metathesis Polymerization
}

\author{
Bahar Bingöl, ${ }^{a} *$ Anja Kroeger, ${ }^{\mathrm{b}}$ Patric Jannasch ${ }^{\mathrm{a} *}$ \\ ${ }^{a}$ Department of Chemistry, Polymer and Materials Chemistry, Lund University, P.O.B. 124, SE \\ 22100 Lund, Sweden. \\ ${ }^{\mathrm{b}}$ Max Planck Institute for Polymer Research, Ackermannweg 10, D-2128 Mainz, Germany. \\ * Corresponding Authors. \\ Bahar Bingol \\ Department of Chemistry, Polymer and Materials Chemistry, Lund University, P.O.B. 124, SE \\ 22100 Lund, Sweden. Tel: (+46) 462228279 Fax: (+46) 462224012 E-mail: \\ bahar.bingol@chem.lu.se \\ Patric Jannasch \\ Department of Chemistry, Polymer and Materials Chemistry, Lund University, P.O.B. 124, SE \\ 22100 Lund, Sweden. Tel: (+46) 462229860 Fax: (+46) 462224012 E-mail: \\ patric.jannasch@chem.lu.se
}

Keywords

Block copolymers

Phosphonated norbornene imides

Ring opening metathesis polymerization 
ABSTRACT. Phosphonated polymers with a well-defined molecular weight, composition, and architecture have been prepared via ring opening metathesis polymerization (ROMP) of diethyl phosphonate norbornene imides at room temperature for the first time. ROMP gave a broad range of phosphonated homopolymers, statistical, diblock and triblock copolymers based on poly(norbornene imide)s with low polydispersity (1.09-1.32) Complete hydrolysis of diethyl phosphonate poly(norbornene imide)s under mild conditions yielded the phosphonic acid derivatives. Thermogravimetric analysis indicated high thermal and thermo-oxidative stability of the polymers. Free standing and transparent films with good mechanical stability were obtained from the phosphonic acid functional homopolymers, diblock and triblock copolymers. Combining these basic properties with the advantages mentioned above make ROMP a promising pathway for accessing a wide diversity of phosphonated macromolecular structures. These new phosphonated polymers will open new perspectives in advanced application areas such as medicine and membrane science, which require a high level of control over polymer structure.

\section{Introduction}

Phosphonic acid functional polymers are interesting for various medical applications such as implant coatings, $[1,2]$ and membrane technologies such as water purification, [3] and fuel cells [4-6] due to the unique combination of acidity, stability, proton conductivity, and metal binding of the phosphonic acid functionality. Despite these attractive properties and potential applications, there is a current lack of direct pathways to prepare well-defined phosphonic acid functional polymers from phosphonated monomers, and thus also lack of knowledge of the fundamental properties of such materials. This is mostly due the unusual polymerization 
behavior of phosphonated monomers leading to difficulties during synthesis [6-10]. Direct access to phosphonic acid functional polymers with controlled molecular properties is critical in order to obtain polymer libraries of complex macromolecular architectures for structure-property relationship studies, which will open perspectives in new applications.

Various polymerization techniques including anionic, $[6,8,11,12]$ condensation $[13]$ and free radical polymerization, $[7,14-19]$ as well as controlled radical polymerization $[20,21]$ have been employed to prepare phosphonic acid functional polymers by direct polymerization of phosphonated monomers. Among these techniques, controlled radical and anionic polymerization have the potential to produce polymers with well-defined structures. Still, these techniques have shown to give homopolymers, block and graft copolymers with limited conversions and degrees of polymerizations of phosphonated monomers $[6,8,11,12,21]$. These efforts significantly improved the ability to prepare phosphonated polymers with varying macromolecular architectures. However, they did not lead to truly living polymerization reactions, which are crucial for precise control over the polymer structure.

More recently, rare-earth metal mediated polymerization has been employed to vinyl phosphonates as an alternative [22-24]. High molecular weight $\left(\mathrm{M}_{\mathrm{w}} \sim 1 \times 10^{6} \mathrm{~g} / \mathrm{mol}\right)$ homopolymers as well as diblock and statistical copolymers with low polydispersity and degree of polymerization close to the initial monomer-to-catalyst ratio were obtained at $30{ }^{\circ} \mathrm{C}$. Diblock copolymers were prepared in nearly quantitative yield via sequential polymerization, where a vinyl phosphonate was added after complete polymerization of methyl methacrylate. Statistical copolymers were made by simultaneous addition of different dialkyl vinyl phosphonates. These results present new and exciting opportunities to synthesize macromolecular architectures directly from phosphonated monomers. Still, the rare-earth metal mediated polymerization has 
severe limitations. These limitations include the inability of the polymerization to yield diblock copolymers via sequential polymerization if the non-phosphonated monomer (e.g. methyl methacrylate) is added after the polymerization of phosphonated monomer, and statistical copolymers by simultaneous addition of phosphonated and non-phosphonated vinyl monomers. This has been ascribed to the strong binding of phosphonates to the rare-earth metal center, which inhibits the coordination of an acrylic monomer at the active site. ${ }^{[2]}$ These features currently limit the level of complexity of the macromolecular architectures accessible via rareearth metal mediated polymerization, and the flexibility in fine-tuning the polymer properties. For example, triblock copolymers having phosphonates sites either at the end or in the middle of the polymer chain are currently inaccessible via rare-earth metal mediated polymerization. Moreover, the catalyst used in rare-earth metal mediated polymerization is not commercially available, which further limits the access to well-defined phosphonated polymers.

ROMP is a controlled living polymerization method that leads to a large diversity of functional polymers with precisely controlled properties without requiring protecting group chemistry because of the high functional tolerance of the olefin metathesis catalyst [25]. This is a distinct advantage over other living polymerization techniques, such as anionic polymerization and controlled radical polymerizations. Despite these interesting features, the literature on ROMP of phosphonated monomers is very limited. The first report on the compatibility of ROMP with phosphonated monomers was published in 2009. In this study, low molecular weight amphiphilic block copolymers from a phosphonated and non-phosphonated oxanorbornene imide were synthesized via ROMP [26]. However, since then, this topic has not received further attention until a very recent publication of a study with a focus on the biological properties of poly(norbornene)s [27]. The analysis of the molecular weights and molecular 
weight distributions via size exclusion chromatography (SEC) indicated that the polymers obtained in both studies have low polydispersities, which hinted a living nature of the polymerization. None of these studies reported the evolution of monomer conversion or molecular weight during the polymerization, which is necessary to prove the living ROMP. Although previous reports briefly point out ROMP as an alternative pathway to phosphonated polymers, the advantages of ROMP were not fully identified and exploited to extent the ability to prepare phosphonated polymers that are currently inaccessible using other polymerization methods due to synthetic limitations. Moreover, the basic properties of the resulting materials were not investigated. It is worth to note that unsaturated polyphosphoesters, [28] fatty acid derived phosphorous-containing polyesters, [29] and phosphonic acid functionalized polyolefins [30] were prepared using step growth metathesis polycondensation technique, which allowed precise placing of phosphorous containing functionalities into the polymers. Although Grubbstype catalysts are used in both step growth metathesis polycondensation and ROMP, these techniques are different.

In the current paper, we present the advantageous features of ROMP with regard to synthesis of phosphonated polymers with controlled molecular structures and exploit these features to prepare phosphonated polymers, in which the ionic groups are directed to certain parts of the polymer chain. To this end, we prepared homopolymers as well as statistical, diblock and triblock copolymers from phosphonated and non-phosphonated norbornene imides. This is the first report on phosphonated triblock copolymers, which are currently inaccessible via other polymerization methods directly from phosphonated monomers. In addition, we report on the basic properties of the resulting polymers. To this end, we studied the thermal stability, film forming ability and water uptake of the resulting polymers. The ability to prepare polymers with 
controlled spatial distribution of phosphonic acid combined with knowledge on their properties is essential to develop advanced materials based on phosphonic acid polymers with new and improved features for implant coatings, water purification and fuel cells.

\section{Materials and Methods}

\subsection{Materials}

The following reagents and solvents were used as received: cis-5-norbornene-exo-2,3icarboxylic anhydride (Sigma Aldrich, 95\%), diethyl 2-bromoethylphosphonate (Sigma Aldrich, 97\%), potassium carbonate (Sigma Aldrich, 99\%), acetone (Across, 99.8\%), $\left(\mathrm{H}_{2} \mathrm{IMes}\right)\left(\mathrm{PCy}_{3}\right)(\mathrm{Cl})_{2} \mathrm{Ru}=\mathrm{CHPh}$ (Sigma Aldrich), ethyl vinyl ether (Sigma Aldrich, 98\%), lithium bromide (Sigma Aldrich), tetrahydrofuran (Sigma Aldrich, HPLC grade), N-methyl pyrrolidone (Sigma Aldrich, HPLC grade), dimethyl acetamide (Sigma Aldrich, HPLC grade), chloroform (Sigma Aldrich, HPLC grade), toluene (Sigma Aldrich, HPLC grade) and dimethyl sulfoxide (Acros, HPLC grade). N,N'-dimethyl formamide, and dicloromethane were purified by passage through solvent purification. Catalyst $\left(\left[\left(\mathrm{H}_{2} \mathrm{IMes}\right)(\mathrm{pyr})_{2}(\mathrm{Cl})_{2} \mathrm{Ru}=\mathrm{CHPh}\right], \quad[31]\right.$ diethyl (2aminoethyl)phosphonate, [32] N-(butyl)-cis-5-norbornene-exo-2,3-dicarboximide, [33] and diethyl (6-bromohexyl)phosphonate [34] were prepared according to literature.

\subsection{Methods}

NMR spectra of the monomers and polymers were recorded on a Bruker $400 \mathrm{MHz}$ spectrometer, whereas ROMP kinetics was followed on a Bruker $500 \mathrm{MHz}$ spectrometer. Chemical shifts are expressed in parts per million using residual solvent protons as internal standard (5.32 ppm for $\mathrm{CH}_{2} \mathrm{Cl}_{2}, 7.28 \mathrm{ppm}$ for $\mathrm{CDCl}_{3}, 4.80 \mathrm{ppm}$ and $3.30 \mathrm{ppm}$ for $\mathrm{d}_{4}-$ methanol, $2.50 \mathrm{ppm}$ for $\mathrm{d}_{6}$-dimethyl sulfoxide). Coupling constants, $\mathrm{J}$, are reported in Hertz $(\mathrm{Hz})$, and splitting patterns are designated as $\mathrm{s}$ (singlet), $\mathrm{d}$ (doublet), $\mathrm{t}$ (triplet), and $\mathrm{m}$ (multiplet). 
Conventional SEC was performed using an Agilent 1260 Infinity system equipped with an ERC refractive index detector and a set of SEC Polymer Standard Service GmbH (PSS) columns (GRAM1000, GRAM1000, GRAM100 $10 \mu \mathrm{m}, 8$ x $300 \mathrm{~mm}$ with a separation range of 300 to $1 \times 106 \mathrm{~g} \mathrm{~mol}^{-1}$ ). Calibration was done using polystyrene standards. size exclusion chromatography-multiangle laser light scattering (SEC-MALLS) measurements were performed on an Agilent 1260 Infinity system coupled to a DAWN-EOS laser light scattering detector (Wyatt Technologies) equipped with a He-Ne laser operating at a laser wavelength of $\lambda_{0}=685$ $\mathrm{nm}$ and an ERC refractive index detector. Chromatographic separation was performed by using a PSS GRAM linear M $10 \mu \mathrm{m}$ column $(8 \mathrm{x} 300 \mathrm{~mm})$ with a separation range of 500 to $1 \mathrm{x} 106 \mathrm{~g}$ $\mathrm{mol}^{-1}$. The mobile phase for all SEC experiments was N,N-dimethylformamide (DMF) with 1 $\mathrm{g} / \mathrm{L}$ lithium bromide $(\mathrm{LiBr})$. An injection volume of $100 \mu \mathrm{L}$ and $25 \mu \mathrm{L}$ of 0.25 wt $\%$ polymer solutions (prepared in $\mathrm{DMF} / \mathrm{LiBr}$ at room temperature, stirred for $1 \mathrm{~h}$ ) for conventional SEC and SEC-MALLS, respectively, and a flow rate of $1.0 \mathrm{ml} \mathrm{min}^{-1}$ was used for all measurements. All samples were cleaned prior by filtration through PTFE membrane filters with a pore size of 0.45 $\mu \mathrm{m}$ (Millipore, Millex-FH). All measurements were carried out at $60{ }^{\circ} \mathrm{C}$. In SEC-MALLS the refractive index increment of the samples was determined under the assumption of a nondissipative mass recovery. All data were recorded and evaluated by using PSS-WinGPC UniChrom (PSS).

Thermogravimetric analysis (TGA) was conducted using a Q500 thermogravimetric analyzer from TA Instruments. The thermal stability of polymers was investigated between room temperature and $600{ }^{\circ} \mathrm{C}$ under both nitrogen and air. The scan rate was $10{ }^{\circ} \mathrm{C} / \mathrm{min}$ and $1{ }^{\circ} \mathrm{C} / \mathrm{min}$ for measurements under nitrogen and air, respectively. The polymers were annealed at $150{ }^{\circ} \mathrm{C}$ for 10 min prior to the scanning cycle. Differential scanning calorimetry (DSC) was performed 
to determine $\mathrm{T}_{\mathrm{g}}$ of polymers using TA Instruments Q1000 DSC. Each sample was examined using sealed pans with a heating and cooling rate of $10{ }^{\circ} \mathrm{C} / \mathrm{min}$. Prior to the glass transition $\left(\mathrm{T}_{\mathrm{g}}\right)$ measurement, phosphonated polymers were first heated from 40 to $200{ }^{\circ} \mathrm{C}$, and then cooled to $70{ }^{\circ} \mathrm{C} . \mathrm{T}_{\mathrm{g}}$ was determined from the second heating curve obtained by ramping the polymers from 10 to $200{ }^{\circ} \mathrm{C}$. To follow phosphonic acid anhydride formation in phosphonic acid functional polymers, the following temperature program was employed: $40{ }^{\circ} \mathrm{C} \rightarrow 20{ }^{\circ} \mathrm{C} \rightarrow 100{ }^{\circ} \mathrm{C} \rightarrow 20{ }^{\circ} \mathrm{C}$ $\rightarrow 150{ }^{\circ} \mathrm{C} \rightarrow 20{ }^{\circ} \mathrm{C} \rightarrow 200{ }^{\circ} \mathrm{C} \rightarrow 20{ }^{\circ} \mathrm{C}$.

\subsection{Monomer Synthesis and Homopolymerization}

Synthesis of N-(ethyl diethyl phosphonate)-cis-5-norbornene-exo-2,3-dicarboximide (1). (Procedure a in Scheme 1). A two-neck round-bottom flask was charged with cis-5-norborneneexo-2,3-dicarboxyimide (1g, 6.0 moles), potassium carbonate (1.65 g, 11.9 mmoles) and $10 \mathrm{~mL}$ dry acetone under nitrogen. Diethyl (2-bromoethyl)phosphonate $(0.2 \mathrm{~mL}, 2.7$ moles) was added after refluxing the mixture for $1 \mathrm{~h}$, and the mixture was allowed to reflux for 2 days. Potassium carbonate was filtered off, and acetone was removed. Purification with flash chromatography using hexane/ethyl acetate $(1: 1)$ afforded the product. (0.46 g, 52\%).

(Procedure b in Scheme 1). A round-bottom flask was charged with cis-5-norbornene-exo-2,3anhydride (0.5 g, 3.0 mmoles). To the flask was added $3.75 \mathrm{~mL}$ toluene, followed by diethyl (2aminoethyl)phosphonate (0.82 g, 4.5 mmoles.) and triethylamine ( $90 \mu \mathrm{L}, 0.3$ mmoles). A DeanStark trap was attached to the flask, and the reaction mixture was heated to reflux. Once complete consumption of cis-5-norbornene-exo-2,3-anhydride was observed by thin layer chromatography, the reaction mixture was concentrated under reduced pressure. The residue was dissolved in $10 \mathrm{~mL} \mathrm{CH}_{2} \mathrm{Cl}_{2}$ and washed with $0.1 \mathrm{~N} \mathrm{HCl}(5 \mathrm{~mL})$ and brine $(5 \mathrm{~mL})$. The product was purified by silica gel chromatography (1:1 hexanes/ ethyl acetate) to yield $1 .(0.24 \mathrm{~g}, 50 \%)$ 
${ }^{1} \mathrm{H}$ NMR (400 MHz, $\left.\mathrm{CDCl}_{3}\right) \delta: 6.26(2 \mathrm{H}, \mathrm{t}, \mathrm{J}=1.8 \mathrm{~Hz}), 4.19-4.00(4 \mathrm{H}, \mathrm{m}), 3.77-3.63(2 \mathrm{H}, \mathrm{m})$, 3.25-3.23 (2H, m), $2.65(2 \mathrm{H}, \mathrm{d}, \mathrm{J}=1.3), 2.15-1.96(2 \mathrm{H}, \mathrm{m}), 1.48(1 \mathrm{H}, \mathrm{dt}, \mathrm{J}=9.9), 1.31(6 \mathrm{H}, \mathrm{t}, \mathrm{J}=$ 7.0), 1.24-1.19 (1H, m).

${ }^{13} \mathrm{C}$ NMR (100 MHz, $\left.\mathrm{CDCl}_{3}\right) \delta$ 177.42, 137.62, 61.89 (d, J=6.46), 47.81, 45.14, 42.77, 32.77(d, $\mathrm{J}=1.1), 23.98(\mathrm{~d}, \mathrm{~J}=140.24), 16.37(\mathrm{~d}, \mathrm{~J}=5.93)$.

${ }^{31} \mathrm{P}$ NMR $\left(161 \mathrm{MHz}, \mathrm{CDCl}_{3}\right) \delta 26.50$.

Synthesis of N-(hexyl diethyl phosphonate)-cis-5-norbornene-exo-2,3-dicarboximide (2). A two-neck round-bottom flask was charged with cis-5-norbornene-exo-2,3-dicarboxylic imide (0.5g, 3.0 mmoles), potassium carbonate $(0.85 \mathrm{~g}, 6.0$ moles $)$ and $4 \mathrm{~mL}$ dry $\mathrm{N}, \mathrm{N}$-dimethyl formamide under nitrogen. Next, the mixture was heated at $50{ }^{\circ} \mathrm{C}$ for $1 \mathrm{~h}$ before adding diethyl (6-bromohexyl)phosphonate $(0.46 \mathrm{~g}, 1.5$ moles $)$ in $1 \mathrm{~mL} \mathrm{~N}, \mathrm{~N}$-dimethyl formamide. The mixture was refluxed for 2 days. Potassium carbonate was filtered off, and acetone was removed. Purification with flash chromatography using first hexane and then ethyl acetate yielded the product. $(1 \mathrm{~g}, 86 \%)$.

${ }^{1} \mathrm{H}$ NMR $\left(400 \mathrm{MHz}, \mathrm{CDCl}_{3}\right) \delta 6.0(2 \mathrm{H}, \mathrm{t}, \mathrm{J}=1.8 \mathrm{~Hz}), 4.20-4.02(4 \mathrm{H}, \mathrm{m}), 3.47(2 \mathrm{H}, \mathrm{t}, \mathrm{J}=7.44)$, 3.31-3.26 (2H, m), $2.68(2 \mathrm{H}, \mathrm{d}, \mathrm{J}=1.1), 1.84-1.09(18 \mathrm{H}, \mathrm{m})$.

${ }^{13} \mathrm{C}$ NMR $\left(100 \mathrm{MHz}, \mathrm{CDCl}_{3}\right) \delta$ 178.07, 137.83, 61.42 (d, J=6.2), 47.80, 45.17, 42.72, 38.57, 30.11 (d, J= 16.77), 4.56, 26.04 (d, J=17.15), 24.93, 22.31 (d, J=5.15), 16.47 (d, J=5.9).

${ }^{31} \mathrm{P}$ NMR $\left(161 \mathrm{MHz}, \mathrm{CDCl}_{3}\right) \delta 32.4$.

Synthesis of Homopolymers (5-8). Monomers 1 and $\mathbf{2}$ were polymerized via ROMP in the presence of ruthenium olefin catalyst $3\left[\left(\mathrm{H}_{2} \mathrm{IMes}\right)(\mathrm{pyr})_{2}(\mathrm{Cl})_{2} \mathrm{Ru}=\mathrm{CHPh}\right]$. In a typical polymerization, a vial was charged with phosphonated norbornene imide and a stirbar under nitrogen flow. A volume of $\mathrm{CH}_{2} \mathrm{Cl}_{2}$ was added to the vial to obtain a $0.1 \mathrm{M}$ monomer solution. 
The desired amount of catalyst as a stock solution in $\mathrm{CH}_{2} \mathrm{Cl}_{2}$ was then injected into the vial. The stock solution of catalyst was prepared to contain the required quantity of catalyst in 1/10th volume of the monomer solution. The polymerization was quenched by addition of ethyl vinyl ether after full conversion of monomer to polymer as followed by thin layer chromatography. The reaction mixture was stirred for an additional $15 \mathrm{~min}$ before precipitation into diethyl ether/hexanes (1:1). The products were recovered by decanting off the supernatant and scraping the gooey solids off of the sides of the beaker. They were dried under vacuum for $24 \mathrm{~h}$.

5- 7. ${ }^{1} \mathrm{H}$ NMR (400 MHz, $\left.\mathrm{CDCl}_{3}\right) \delta 5.8$ (b), 5.53 (b), 4.12 (b), 3.1 (b), 3.30 (b), 3.12 (b), 3.03 (b), $2.83(b), 2.76(b), 2.12(b), 1.68(b), 1.35(b)$.

5- 7. ${ }^{31} \mathrm{P}$ NMR $\left(161 \mathrm{MHz}, \mathrm{CDCl}_{3}\right) \delta 26.93$ (b).

5- 7. ${ }^{31} \mathrm{P}$ NMR (161 MHz, $\mathrm{d}_{6}$-dimethyl sulfoxide) $\delta 27.18$ (b).

8. ${ }^{1} \mathrm{H}$ NMR (400 MHz, $\mathrm{CDCl}_{3}$ ) $\delta 5.80$ (b), 5.54 (b), 4.10 (b), 3.45 (b), 3.29 (b), 3.07 (b), 2.77 (b), 2.69 (b), 2.43 (b), 1.77-1.48 (b), 1.47-1.24 (b).

8. ${ }^{31} \mathrm{P}$ NMR $\left(161 \mathrm{MHz}, \mathrm{CDCl}_{3}\right) \delta 32.25$ (b).

8. ${ }^{31}$ P NMR (161 MHz, $\mathrm{d}_{6}$-dimethyl sulfoxide) $\delta 36.60$ (b).

ROMP Kinetics of Phosphonated Norbornene Imides. The polymerization kinetics of phosphonated norbornene imides was followed via ${ }^{1} \mathrm{H}$ NMR spectroscopy using a $500 \mathrm{MHz}$ Bruker NMR Instrument. Stock solutions of monomers $1(0.15 \mathrm{mM})$ and $2(0.17 \mathrm{mM})$ and catalyst in $\mathrm{CD}_{2} \mathrm{Cl}_{2}$ were prepared in oven-dried NMR tubes fitted with septum screw caps under nitrogen atmosphere. The concentration of catalyst solution was adjusted such that to contain the required quantity of catalyst in 1/10th of the volume of the monomer solution. The catalyst solution was then added rapidly to the NMR tube through the septum-screw cap via syringe and then NMR tube was inverted twice to ensure mixing and placed in the NMR spectrometer. The 
polymerization was monitored until complete consumption of $\mathbf{1}$ and $\mathbf{2}$ were observed. All experiments were run without lock, and number of scans per spectrum was 1 .

\subsection{Copolymerization}

Synthesis of Diblock Copolymers (9-10). To prepare 9, a vial was charged with N(butyl)-cis-5-norbornene-exo-2,3-dicarboximide 4 (142.4 mg, 0. 64 mmoles) and a stirbar under nitrogen flow. $\mathrm{CH}_{2} \mathrm{Cl}_{2}(11.7 \mathrm{~mL})$ was added to the vial. The desired amount of catalyst $(2.9 \mathrm{mg}$, $3.9 \mu$ moles $)$ as a stock solution in $\mathrm{CH}_{2} \mathrm{Cl}_{2}(1 \mathrm{~mL})$ was then injected into the vial. The reaction was allowed to proceed at room temperature under nitrogen flow until complete conversion of $\mathrm{N}$ (butyl)-cis-5-norbornene-exo-2,3-dicarboximide 4. Monomer 1 (206.2 mg, 0.63 mmoles) was dissolved in $450 \mu \mathrm{L}$ dichloromethane, and $400 \mu \mathrm{L}$ of this solution was added to the polymerization medium. The polymerization was quenched after complete disappearance of $\mathbf{1}$ by addition of ethyl vinyl ether. The block copolymer was isolated after precipitation in a mixture of diethyl ether/hexane (1:1). To prepare 10, monomer 1 (47.49 mg, 0.14 mmoles) was dissolved in $\mathrm{CH}_{2} \mathrm{Cl}_{2}(3 \mathrm{~mL})$. The catalyst $(0.7 \mathrm{mg}, 0.99 \mu$ moles $)$ as a stock solution in $\mathrm{CH}_{2} \mathrm{Cl}_{2}(0.3 \mathrm{~mL})$ was injected to the vial. After complete consumption of $\mathbf{1}$, a solution of $\mathrm{N}$-(butyl)-cis-5-norborneneexo-2,3-dicarboximide $4(26 \mathrm{mg}, 0.12)$ in $0.1 \mathrm{~mL} \mathrm{CH}_{2} \mathrm{Cl}_{2}$ was introduced to the reaction medium. The polymerization was quenched, and the polymer was isolated as described in the synthesis of 9 .

9- 10. ${ }^{1} \mathrm{H}$ NMR (400 MHz, $\left.\mathrm{CDCl}_{3}\right) \delta 5.78$ (b), 5.54 (b), 4.12 (b), 3.74 (b), 3.46 (b), 3.28 (b), 3.04 (b), 2.78 (b), 2.70 (b), 2.10 (b), 1.82-1.4 (b), 1.35 (b), 0.94 (b).

9- 10. ${ }^{31} \mathrm{P}$ NMR $\left(161 \mathrm{MHz}, \mathrm{CDCl}_{3}\right) \delta 26.85$.

9- 10. ${ }^{31}$ P NMR (161 MHz, $\mathrm{d}_{6}$-dimethyl sulfoxide) $\delta 27.19$ (b). 
Synthesis of Triblock Copolymers (21-22). To prepare 21, a vial was charged with monomer 1 (138.9 mg, $0.42 \mathrm{mmol})$ and a stirbar under nitrogen flow. $\mathrm{CH}_{2} \mathrm{Cl}_{2}(12.3 \mathrm{~mL})$ was added to the vial. The desired amount of catalyst $(2.88 \mathrm{mg}, 3.9 \mu$ moles $)$ as a stock solution in $\mathrm{CH}_{2} \mathrm{Cl}_{2}(0.5 \mathrm{~mL})$ was then injected into the vial. Monomer $4(101.35 \mathrm{mg}, 0.46 \mathrm{mmol})$ was added in $0.5 \mathrm{~mL} \mathrm{CH}_{2} \mathrm{Cl}_{2}$ to the polymerization medium after complete consumption of 2 . After complete polymerization of $\mathbf{4}$, monomer $1(113.36 \mathrm{mg}, 0.35 \mathrm{mmol})$ was introduced to the reaction in $0.5 \mathrm{~mL} \mathrm{CH}_{2} \mathrm{Cl}_{2}$. The polymerization was quenched after complete disappearance of 4 by addition of ethyl vinyl ether. The block copolymer was isolated after precipitation in a mixture of diethyl ether/hexane (1:1). To obtain 22, a vial was charged with N-(butyl)-cis-5norbornene-exo-2,3-dicarboximide $4(61.4 \mathrm{mg}, 0.28 \mathrm{mmoles})$ and a stirbar under nitrogen flow. $\mathrm{CH}_{2} \mathrm{Cl}_{2}(12.5 \mathrm{~mL})$ was added to the vial. Monomer 1 (182 $\mathrm{mg}, 0.56$ mmoles) was introduced to the polymerization medium in $0.5 \mathrm{~mL} \mathrm{CH}_{2} \mathrm{Cl}_{2}$ after complete consumption of monomer 4 . After polymerization of 1 was complete, monomer 4 (47.56 mg, 0.22 mmoles) were added to the medium in $0.5 \mathrm{~mL} \mathrm{CH} \mathrm{Cl}_{2}$. The polymerization was quenched and the polymer was isolated in the same manner as $\mathbf{2 1}$.

21. ${ }^{1} \mathrm{H}$ NMR (400 MHz, $\mathrm{CDCl}_{3}$ ) $\delta 5.78$ (b), 5.53 (b), 4.12 (b), 3.72 (b), 3.45 (b), 3.28 (b), 3.05 (b), 2.77 (b), 2.70 (b), 2.12 (b), 1.84-1.41 (b), 1.35 (b), 0.94 (b).

21. ${ }^{31} \mathrm{P}$ NMR $\left(161 \mathrm{MHz}, \mathrm{CDCl}_{3}\right) \delta 26.87$.

21. ${ }^{31} \mathrm{P}$ NMR (161 MHz, $\mathrm{d}_{6}$-dimethyl sulfoxide) $\delta 27.17$.

22. ${ }^{1} \mathrm{H}$ NMR (400 MHz, $\mathrm{CDCl}_{3}$ ) $\delta 5.78$ (b), 5.53 (b), 4.12 (b), 3.74 (b), 3.45 (b), 3.29 (b), 3.03 (b), 2.77 (b), 2.70 (b), 2.12 (b), 1.76-1.45 (b), 1.35 (b), 0.94 (b).

22. ${ }^{31} \mathrm{P}$ NMR $\left(161 \mathrm{MHz}, \mathrm{CDCl}_{3}\right) \delta 26.94$.

22. ${ }^{31}$ P NMR (161 MHz, $\mathrm{d}_{6}$-dimethyl sulfoxide) $\delta$ 27.22. 
Synthesis of Statistical Copolymers (11-12). To prepare 11, a vial was charged with N(butyl)-cis-5-norbornene-exo-2,3-dicarboximide 4 (13.60 mg, 62.0 mmoles), 1 (154.6 mg, 472.3 mmoles), and a stirbar under nitrogen flow. $\mathrm{CH}_{2} \mathrm{Cl}_{2}(5.1 \mathrm{~mL})$ was added to the vial. The desired mount catalyst $3(3.62 \mathrm{mg}, 4.9 \mathrm{mmol})$ was introduced in $0.50 \mathrm{~mL} \mathrm{CH}_{2} \mathrm{Cl}_{2}$. The reaction was allowed to proceed at room temperature under nitrogen flow until complete conversion. The polymerization was quenched, and the polymer was isolated as described in the synthesis of 9 . To prepare 12, the same procedure as described in the synthesis of 11 was applied. 1 (150.4 mg, $459 \mathrm{mmol}), 4$ (12.0 mg, 54.72), and catalyst (1.15 mg, $1.6 \mu \mathrm{mol})$ were used.

11. ${ }^{1} \mathrm{H}$ NMR (400 MHz, $\mathrm{CDCl}_{3}$ ) $\delta 5.78$ (b), 5.54 (b), 4.12 (b), 3.72 (b), 3.47 (b), 3.29 (b), 3.14 (b), 3.05 (b), 2.85 (b), 2.78 (b), 2.13 (b), 1.62 (b), 1.36 (b), 0.90 (b).

11. ${ }^{31} \mathrm{P}$ NMR (400 MHz, $\left.\mathrm{CDCl}_{3}\right) \delta 26.91(\mathrm{~b})$.

11. ${ }^{31} \mathrm{P}$ NMR (161 MHz, $\mathrm{d}_{6}$-dimethyl sulfoxide) $\delta 27.16$ (b).

12. ${ }^{1} \mathrm{H}$ NMR (400 MHz, $\left.\mathrm{CDCl}_{3}\right) \delta 5.78$ (b), 5.2 (b), 4.12 (b), 3.1 (b), 3.46 (b), 3.29 (b), 3.05 (b), $2.86(b), 2.77$ (b), $2.16(b), 1.64(b), 1.35$ (b), $0.90(b)$.

12. ${ }^{31} \mathrm{P}$ NMR (161 MHz, $\left.\mathrm{CDCl}_{3}\right) \delta 26.91$ (b).

12. ${ }^{31}$ P NMR (161 MHz, $\mathrm{d}_{6}$-dimethyl sulfoxide) $\delta 27.17$ (b).

\subsection{Hydrolysis}

Hydrolysis of Phosphonated Poly(norbornene imide)s (13-17 and 23-24). To hydrolyze the phosphonated homopolymers, a dry vial was charged with $\mathbf{5 , 6}, \mathbf{7}$ or $\mathbf{8}(150 \mathrm{mg})$ and dry $\mathrm{CH}_{2} \mathrm{Cl}_{2}(6.5 \mathrm{~mL})$ under nitrogen flow. Bromotrimethylsilane $(1.2 \mathrm{~mL})$ was added dropwise. The mixture was heated at $32{ }^{\circ} \mathrm{C}$ overnight. After removing excess bromotrimethylsilane under reduced pressure, $\mathrm{CH}_{2} \mathrm{Cl}_{2}(10 \mathrm{~mL})$ and methanol $(15 \mathrm{~mL})$ were added to the resulting polymer, 
and was allowed to react at room temperature for $48 \mathrm{~h}$. The solvent was removed under reduced pressure, and the remaining solid was washed with $\mathrm{CH}_{2} \mathrm{Cl}_{2}$.

15. ${ }^{31} \mathrm{P}$ NMR (161 MHz, $\mathrm{d}_{6}$-dimethyl sulfoxide) $\delta 22.46$ (b).

16. ${ }^{1} \mathrm{H}$ NMR (400 MHz, d d $^{-m e t h a n o l) ~} \delta 5.45$ (b), 5.25 (b), 3.36-2.99 (b), 2.81 (b) 2.72 (b), 2.39

(b), 1.1 (b), 1.45 (b), 1.4 (b), 1.14 (b), $1.01(b)$.

16. ${ }^{31} \mathrm{P}$ NMR(161 MHz, d $\mathrm{d}_{4}$-methanol) $\delta 28.47$ (b).

16. ${ }^{31}$ P NMR (161 MHz, $\mathrm{d}_{6}$-dimethyl sulfoxide) $\delta 28.47$ (b).

13. ${ }^{31} \mathrm{P}$ NMR (161 MHz, $\mathrm{d}_{6}$-dimethyl sulfoxide) $\delta$ 23.29-21.45 (b).

14. ${ }^{31} \mathrm{P}$ NMR (161 MHz, $\mathrm{d}_{6}$-dimethyl sulfoxide) $\delta 24.03-20.59$ (b).

To hydrolyze the diblock copolymer 9, a dry vial was charged with 9 (130 mg) and dry $\mathrm{CH}_{2} \mathrm{Cl}_{2}(8.2 \mathrm{~mL})$ under nitrogen flow. Bromotrimethylsilane $(1.3 \mathrm{~mL})$ was added dropwise. The mixture was heated at $32{ }^{\circ} \mathrm{C}$ overnight. After removing excess bromotrimethylsilane under reduced pressure, $\mathrm{CH}_{2} \mathrm{Cl}_{2}(4.33 \mathrm{~mL})$ and methanol $(13 \mathrm{~mL})$ were added to the resulting polymer, and was allowed to react at room temperature for $48 \mathrm{~h}$. Solvent was removed under reduced pressure, and the remaining solid was washed with $\mathrm{CH}_{2} \mathrm{Cl}_{2}$ to obtain 17. Triblock 21 and 22 was hydrolyzed as described in the case of diblock copolymers to obtain $\mathbf{2 3}$ and $\mathbf{2 4}$, respectively.

17. ${ }^{1} \mathrm{H}$ NMR (400 MHz, $\mathrm{CDCl}_{3}$ ) $\delta 5.78$ (b), 5.53 (b), 3.47 (b), 3.29 (b), 3.05 (b), 2.94 (b), 2.80 (b), 2.69 (b), $2.43-1.98$ (b), 1.54 (b), 1.28 (b), 0.93 (b).

17. ${ }^{31} \mathrm{P}$ NMR (161 MHz, $\mathrm{d}_{6}$-dimethyl sulfoxide) $\delta 28.47$ (b).

23. ${ }^{31} \mathrm{P}$ NMR (161 MHz, $\mathrm{d}_{6}$-dimethyl sulfoxide) $\delta$ 23.65-21.24 (b).

24. ${ }^{31} \mathrm{P}$ NMR (161 MHz, $\mathrm{d}_{6}$-dimethyl sulfoxide) $\delta 23.51-21.22$ (b).

2.6 Analysis of Polymer and Membrane Properties 
Solubility Test. The solubility of polymers were evaluated in dichloromethane, chloroform, N,N-dimethyl formamide, 1-methyl-2-pyrrolidinone, N,N-dimethylacetamide, dimethyl sulfoxide, toluene, tetrahydrofuran, and water using $5 \mathrm{wt} / \mathrm{v} \%$ polymer solutions in the corresponding solvent.

Film Preparation and Characterization. Films from the phosphonated homopolymers (78) and block copolymer (9) were cast from a dilute solution of the polymers in chloroform (7 $\mathrm{wt} /$ volume $\%$ ) on glass, and were dried under reduced pressure at room temperature. Films from phosphonic acid functional homopolymers (15 and 16) were cast from dilute solutions of the polymer in dimethyl sulfoxide $(5 \mathrm{wt} / \mathrm{v} \%)$. Films from phosphonic acid functional diblock copolymer (17) were cast from dilute solutions of the polymer in dimethyl sulfoxide ( $5 \mathrm{wt} / \mathrm{v} \%$ ) and N,N-dimethyl formamide $(2.3 \mathrm{wt} / \mathrm{v} \%)$. Films from phosphonic acid functional triblock copolymer (24) were cast from dilute solutions of the polymer in dimethyl sulfoxide (2.5 $\mathrm{wt} / \mathrm{v} \%$ ). In all cases, the solutions of phosphonic acid functional polymer in the desired solvent were poured into a petri dish, which is placed into an oven at $80{ }^{\circ} \mathrm{C}$ under nitrogen atmosphere until complete dryness ( $48 \mathrm{~h}$ for films casted from dimethyl sulfoxide and $24 \mathrm{~h}$ for films cast from N,N-dimethyl formamide). Free standing phosphonic acid films were obtained after detachment of the films from Petri dish upon soaking in water at room temperature or at elevated temperatures if necessary.

The water uptake of phosphonic acid functional films was determined gravimetrically using Eq 1 for the phosphonic acid functional polymer films after casting. Dry weights $\left(\mathrm{W}_{\mathrm{dry}}\right)$ were determined after drying the membranes in a vacuum oven at $30^{\circ} \mathrm{C}$ until constant weight, while wet weights $\left(\mathrm{W}_{\text {wet }}\right)$ were recorded after soaking the films in Milli-Q water at various temperatures ranging from 20 to $100{ }^{\circ} \mathrm{C}$. The films were kept at each temperature at least $45 \mathrm{~min}$ 
to reach an equilibrium. The wet films were weighted after excess water was removed using tissue paper.

$\mathrm{W}_{\text {water }}=\left[\left(\mathrm{W}_{\text {wet }}-\mathrm{W}_{\text {dry }}\right) / \mathrm{W}_{\text {dry }}\right] \times 100 \% \quad \mathrm{Eq} 1$.

\section{Results and Discussion}

\subsection{Monomer Synthesis and Homopolymerization}

Substituted exo-norbornenes were chosen as the monomers in the present work because of their ability to undergo living ROMP, as well as their ability to be easily functionalized. We synthesized two phosphonated norbornene imides with different side chain lengths ( $n=2$ and $n=6$ in Scheme 1). The phosphonated imide with the short alkyl chain (1) was prepared by condensation of the exo-anhydride with diethyl (2-aminoethyl)phosphonate, as well as by reacting exo-norbornene imide with diethyl (2-bromoethyl)phosphonate in the presence of potassium carbonate (Scheme 1). The phosphonated imide with the long alkyl chain (2) was obtained by reacting the exo-imide with diethyl (6-bromohexyl)phosphonate in the presence of potassium carbonate. $\mathrm{N}$-alkylation of exo-imides is a more versatile approach compared to the condensation route to obtain phosphonated norbornene imides with longer side chain length because phosphonated alkyl halides are more readily accessible compared to primary amines bearing a phosphonate functionality.

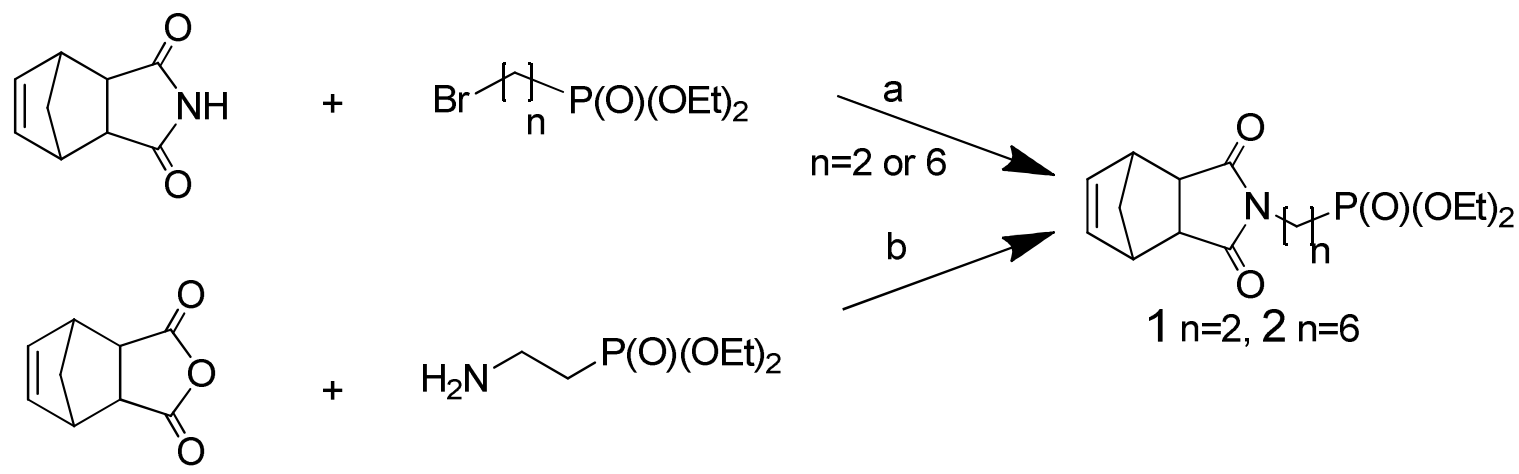

Scheme 1. Synthetic pathway to monomers. 
We monitored the polymerization kinetics of both monomers by ${ }^{1} \mathrm{H}$ NMR spectroscopy in $\mathrm{CD}_{2} \mathrm{Cl}_{2}$ in an NMR tube. The ruthenium olefin metathesis catalyst $\left[\left(\mathrm{H}_{2} \mathrm{IMes}\right)(\mathrm{pyr})_{2}(\mathrm{Cl})_{2} \mathrm{RuCH}=\mathrm{Ph}\right](3)$ was chosen as the initiator due to its ability to produce extremely low polydispersity polymers, and its good benchtop stability [25]. We determined the time-dependence of the monomer conversion by comparing the integral of the olefin proton signals in the ${ }^{1} \mathrm{H}$ NMR spectra of the monomer with those resulting from the polymerization. First order polymerization kinetics was observed, with the slope of the line [ $\left.\mathrm{k}_{\mathrm{observed}}\left(\mathrm{min}^{-1}\right)\right]$ corresponding to the polymerization rate of each of the monomer (Figure 1). These findings proved the living nature of ROMP of phosphonated norbornene imides for the first time.

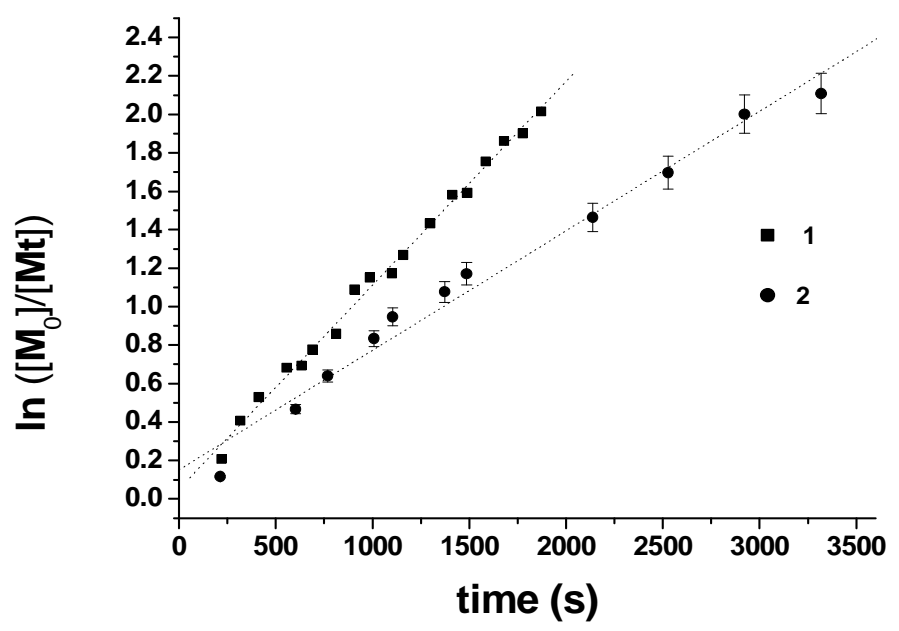

Fig.1. Log plot of the homopolymerization of 1 and 2 [1] = 0.00015 M; [2]=0.00017 M, targeted degree of polymerization for $\mathbf{1}=297$ and for $\mathbf{2}=398$; slope for $\mathbf{1}=0.00106 \mathrm{~s}^{-1}$ and slope for $\mathbf{2}=6.2 \times 10-4{ }^{\mathrm{s}-1}$. Dashed lines present the linear fit of the data. 
To demonstrate the capability of ROMP to form a broad range of phosphonated norbornene imides with controlled molecular weight and low polydispersity, three polymers of varying molecular weights were prepared by treating monomer 1 with varying quantities of catalyst 3 in $\mathrm{CH}_{2} \mathrm{Cl}_{2}$ on the benchtop (Scheme 2a). Quenching with ethyl vinyl ether, and precipitation into ether/hexanes (1:1), afforded the desired products in excellent yields $(\sim 100 \%)$. A representative NMR spectrum with peak assignments is shown in Figure 2. The complete conversion of monomer to polymer was indicated by the total disappearance of the characteristic signal from the monomer olefin protons at $6.26 \mathrm{ppm}$ and the concurrent appearance of the backbone double bond (cis/trans) signals at 5.98 and $5.31 \mathrm{ppm} .{ }^{1} \mathrm{H}$ NMR spectra of polymers with different molecular weights have the same features. The molecular weight and molecular weight distribution analysis was performed using SEC as well as SEC-MALLS, and indicated that the polymers have low polydispersity, and that the molar mass depended on monomer-tocatalyst ratio (Table 1). We also determined the degree of polymerization of the low molecular weight homopolymers 5 and $\mathbf{6}$ by comparing the integrals of the methylene proton signals in the phosphonate ester with those of the phenyl protons arising from the initiator in the ${ }^{1} \mathrm{H}$ NMR spectra. Very similar results were obtained when the integrals of the backbone olefins were compared with the phenyl protons arising from the initiator. Consequently, the theoretical and experimental values for the degree of the polymerization were in good agreement. End group analysis was not possible for sample 7 with the highest molecular weight since no end groups were detected in the spectra even after a high number of scans. 
A)

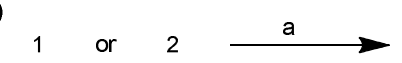

B)

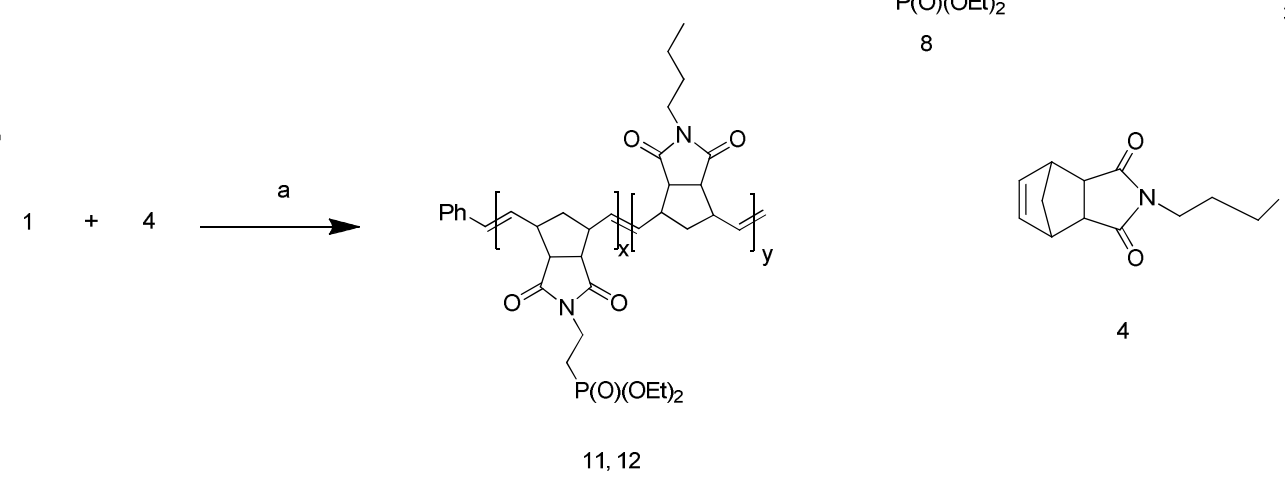

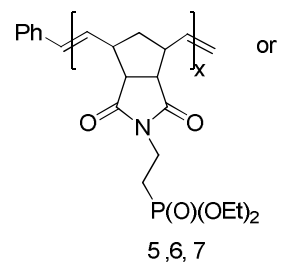

$\mathrm{Ph}$
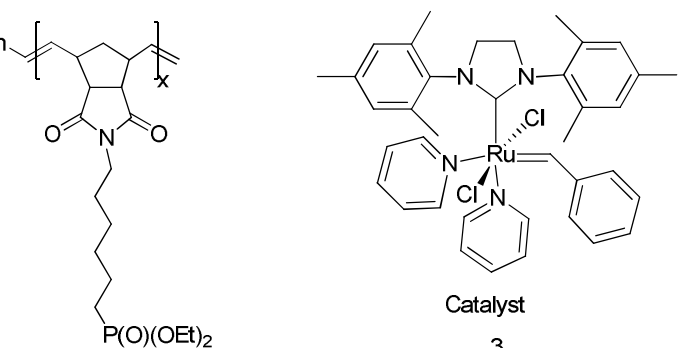

3

Scheme 2. Synthetic route to phosphonated a) homopolymers and b) statistical copolymers of poly(norbornene imide)s. Reagents and conditions (a) i. $\mathrm{CH}_{2} \mathrm{Cl}_{2}, \mathbf{3}$, room temperature (ii) ethyl vinyl ether. 

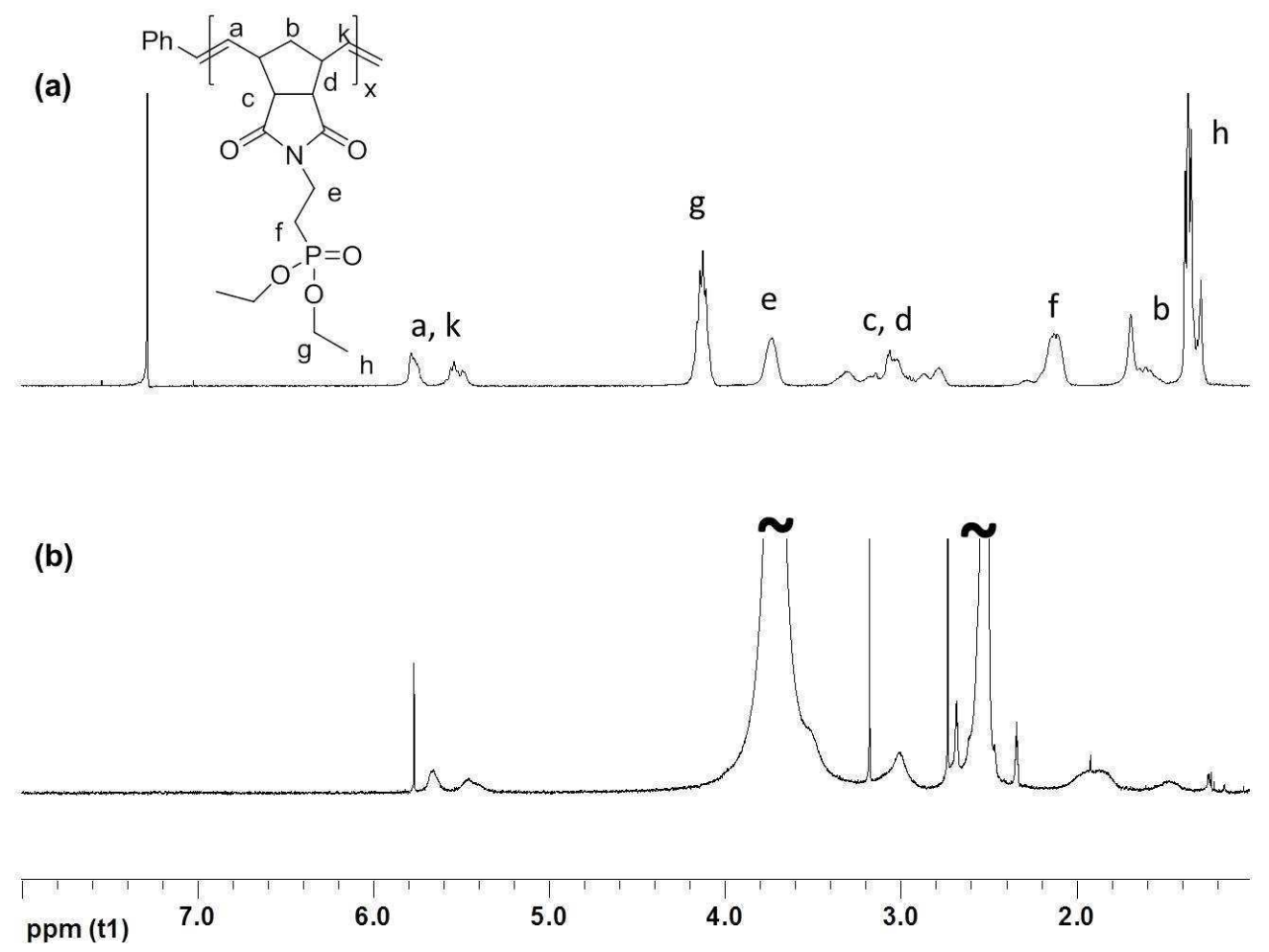

(c)

(d)

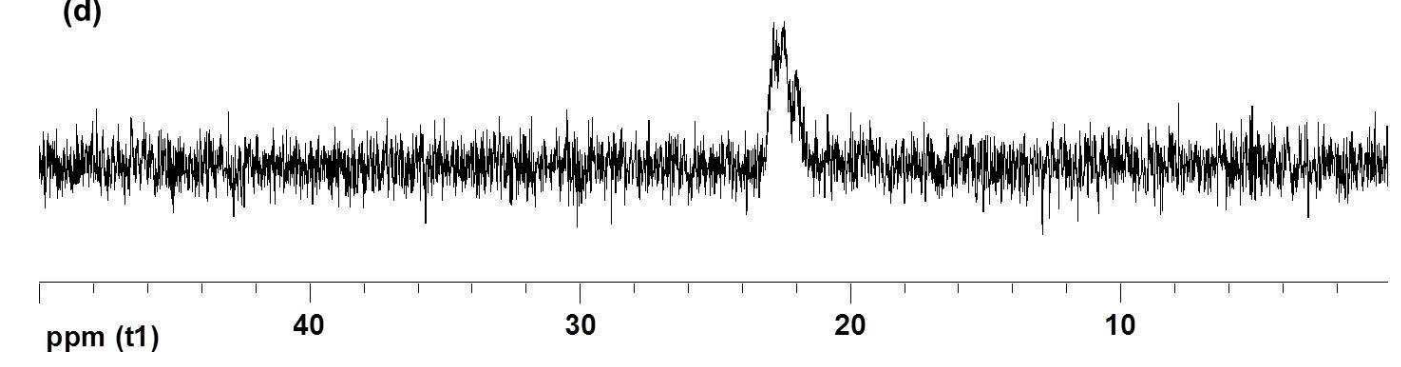

Fig. 2. ${ }^{1} \mathrm{H}$ NMR spectra of homopolymer (a) 7 in $\mathrm{CDCl}_{3}$ and (b) $\mathbf{1 5}$ in $\mathrm{d}_{6}$-dimethyl sulfoxide. ${ }^{31} \mathrm{P}$ NMR spectra of (c) 7 in $\mathrm{CDCl}_{3}$ and (d) 15 in $\mathrm{d}_{6}$-dimethyl sulfoxide. 
Table 1

Molecular characteristics and composition of polymers.

\begin{tabular}{|c|c|c|c|c|c|c|c|c|c|}
\hline Entry & {$[\mathrm{M}] /[\mathrm{C}]$} & $\mathrm{M}_{\mathrm{n}}{ }^{\mathrm{a}}(\mathrm{g} / \mathrm{mol})$ & $\begin{array}{l}\mathrm{M}_{\mathrm{w}}{ }^{\mathrm{a}} \\
(\mathrm{g} / \mathrm{mol})\end{array}$ & $\begin{array}{l}\mathrm{M}_{\mathrm{w}}{ }^{\mathrm{b}} \\
(\mathrm{g} / \mathrm{mol})\end{array}$ & $\begin{array}{l}\mathrm{M}_{\mathrm{w} \text { targetted }} \\
(\mathrm{g} / \mathrm{mol})\end{array}$ & $\mathrm{PDI}^{\mathrm{a}}$ & $\overline{\mathrm{DP}^{\mathrm{c}}}$ & $\begin{array}{l}\text { P:NP } \\
(\mathrm{mol} \%)\end{array}$ & $\begin{array}{l}\mathrm{P}: \mathrm{NP}^{\mathrm{e}} \\
(\mathrm{mol} \%)\end{array}$ \\
\hline 5 & 29 & 9060 & 9970 & 26500 & 9644 & 1.10 & 26 & 100:0 & $\begin{array}{ll}100: 0 \\
\end{array}$ \\
\hline 6 & 93 & 28100 & 30700 & 43900 & 30729 & 1.09 & 86 & 100:0 & 100:0 \\
\hline 7 & 312 & 80500 & 98200 & 12720 & 102138 & 1.22 & NA & 100:0 & 100:0 \\
\hline 8 & 312 & 79200 & 114400 & 143400 & 119918 & 1.22 & NA & 100:0 & 100:0 \\
\hline 9 & 282 & 80500 & 98200 & 83630 & 75014 & 1.22 & $\mathrm{NA}$ & 41:59 & $37: 63$ \\
\hline 10 & 264 & 80300 & 10400 & 109900 & 73675 & 1.28 & $\mathrm{NA}$ & $55: 45$ & $56: 44$ \\
\hline 11 & 107 & 34200 & 37500 & 44300 & 33871 & 1.10 & 83 & $88: 12$ & $87: 13$ \\
\hline 12 & 323 & 91300 & 110500 & 133800 & 102225 & 1.21 & NA & $89: 11$ & $90: 10$ \\
\hline 21 & 311 & 87174 & 112448 & 117000 & 89231 & 1.29 & $\mathrm{NA}$ & 63:37 & $65: 35$ \\
\hline 22 & 269 & 71800 & 94600 & 118600 & 74643 & 1.32 & NA & $52: 48$ & $46: 54$ \\
\hline
\end{tabular}

${ }^{\text {a }}$ PDI: = polydispersity index determined by SEC.

${ }^{\mathrm{b}}$ determined using conventional SEC-MALLS.

${ }^{\mathrm{c}} \mathrm{DP}=$ degree of polymerization determined via ${ }^{1} \mathrm{H}$ NMR spectroscopy.

${ }^{\mathrm{d}} \mathrm{P}=$ phosphonated $\mathrm{NP}=$ non-phosphonated feed composition of monomers.

${ }^{\mathrm{e}} \mathrm{P}=$ phosphonated $\mathrm{NP}=$ non-phosphonated composition of polymer calculated from ${ }^{1} \mathrm{H} \mathrm{NMR}$ spectroscopy data. $\mathrm{NA}=$ not applicable, $\mathrm{M}=$ monomer, $\mathrm{C}=$ catalyst .

To show the applicability of ROMP to a variety of phosphonated norbornene imides, a high molecular weight polymer was synthesized on the benchtop from the phosphonated norbornene imide 2 bearing a long alkyl chain $(n=6)$. The ${ }^{1} \mathrm{H}$ NMR spectrum of the resulting polymer indicated full conversion of the monomer (Figure 3). The resulting polymer 8 had a low polydispersity as determined by SEC and a molecular weight depending on the monomer-to- 
catalyst ratio, as evidenced via SEC-MALLS (Table 1). The $\mathrm{T}_{\mathrm{g}}$ of the phosphonated poly(norbornene imide) with short side chains $(\mathrm{n}=2)$ was found to be $75{ }^{\circ} \mathrm{C}$ (Figure 4), whereas the $\mathrm{T}_{\mathrm{g}}$ of the long chain counterpart $(\mathrm{n}=6)$ was $25^{\circ} \mathrm{C}$. These findings demonstrated for the first time that ROMP can yield low as well as high molecular weight phosphonated polymers with low polydispersity and predetermined molecular weight. This is a distinct advantage of ROMP compared to controlled radical and anionic polymerization, which failed to yield polymers with predetermined molecular weight and low polydispersity up to now $[6,8,20,21]$. 

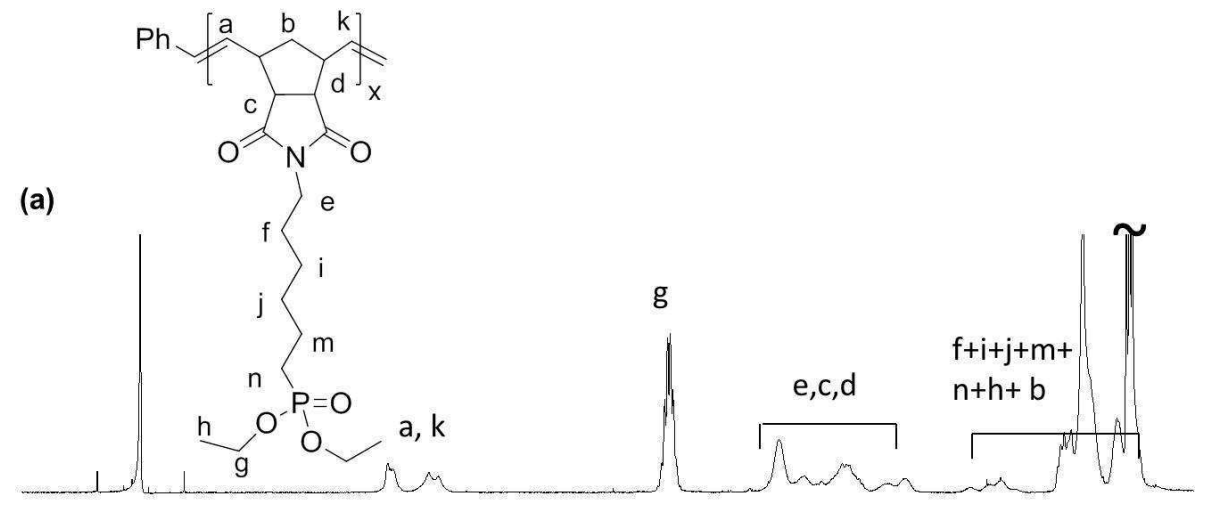

(b)
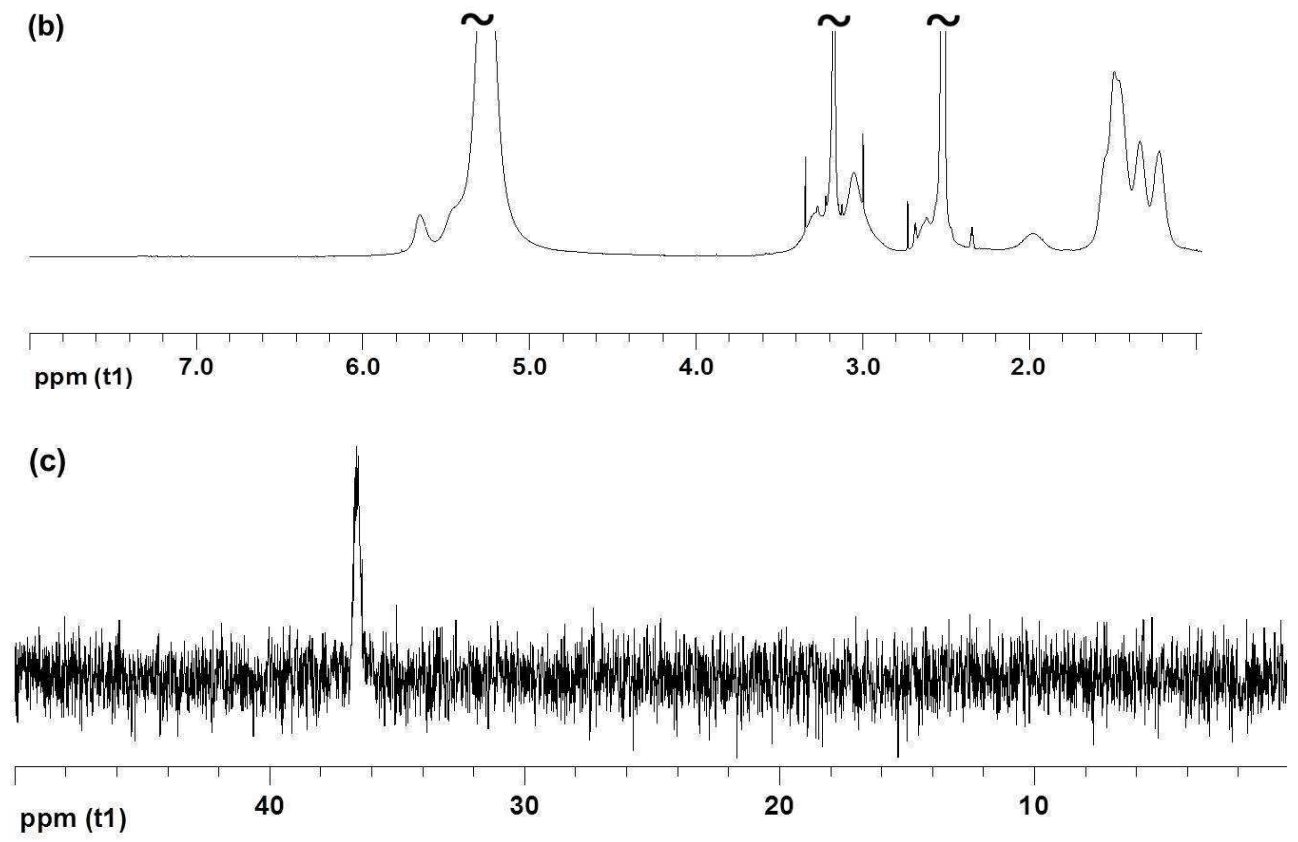

(d)

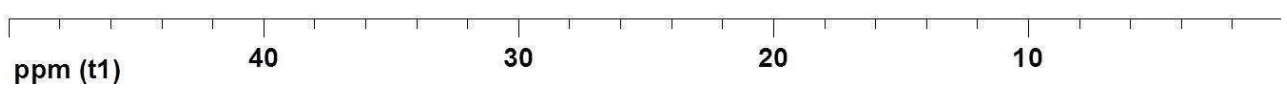

Fig. 3. ${ }^{1} \mathrm{H}$ NMR spectra of homopolymer (a) 8 in $\mathrm{CDCl}_{3}$ (b) 16 in $\mathrm{d}_{6}$-dimethyl sulfoxide, respectively, and ${ }^{31} \mathrm{P}$ NMR spectra of (c) 8 in $\mathrm{d}_{6}$-dimethyl sulfoxide (d) $\mathbf{1 6}$ in $\mathrm{d}_{6}$-dimethyl sulfoxide, respectively. 


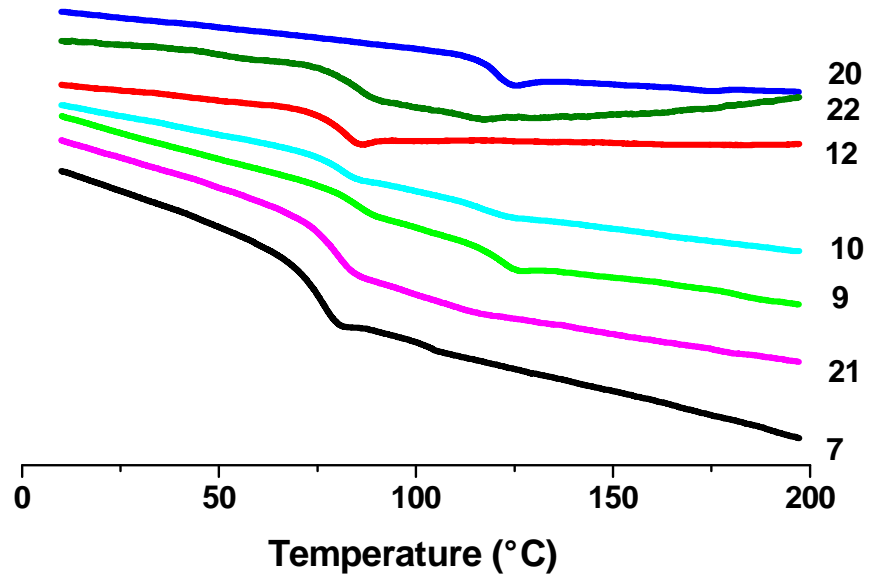

Fig. 4. DSC heating traces of polymers between 0 and $200{ }^{\circ} \mathrm{C}$ recorded at $10{ }^{\circ} \mathrm{C} / \mathrm{min}$.

\subsection{Copolymerization}

Copolymerization is a well-established strategy to tune the polymer properties. To this end, we synthesized both statistical and block copolymers from phosphonated norbornene imide 1 and N-(butyl)-cis-5-norbornene-exo-2,3-dicarboximide 4 via ROMP (Scheme 2-3). Statistical copolymers were prepared by treating a solution of the phosphonated norbornene imide $\mathbf{1}(n=2)$ and $\mathrm{N}$-(butyl)-cis-5-norbornene-exo-2,3-dicarboximide 4 in $\mathrm{CH}_{2} \mathrm{Cl}_{2}$ with the catalyst under nitrogen on the benchtop (Scheme $2 b$ ). We prepared two random copolymers with very similar compositions but different molecular weights (11 and 12). Full conversion of the monomers to polymers was achieved. The ${ }^{1} \mathrm{H}$ NMR spectra of these copolymers show similar features to those of the block copolymers with integral values depending on the copolymer composition. The targeted and experimental molecular weights were in good agreement, and the polymers had a 
low polydispersity (Table 1). Statistical copolymerization was confirmed by the single $T_{g}$ at $\sim 82{ }^{\circ} \mathrm{C}$ observed in the DSC traces (Figure 4). At this point of the study, it was unknown whether 11 and $\mathbf{1 2}$ were random copolymers or if they possessed a gradient composition. These findings indicate the living nature of the copolymerization. ROMP is currently the only polymerization method that has been reported to yield well-defined statistical copolymers from phosphonated and non-phosphonated monomers with well-defined structures.

Diblock copolymers were prepared by sequential copolymerizations of the phosphonated norbornene imide 1 and $\mathrm{N}$-(butyl)-cis-5-norbornene-exo-2,3-dicarboximide $\mathbf{4}$ under nitrogen on the benchtop in $\mathrm{CH}_{2} \mathrm{Cl}_{2}$ (Scheme 3a). We prepared two block copolymers with similar compositions (9 and 10), where we varied the order of monomer addition to study whether that affects the polymerization. The complete disappearance of the characteristic monomer olefin protons (at $6.26 \mathrm{ppm}$ for $\mathbf{1}$, and $6.30 \mathrm{ppm}$ for 4 ), and the simultaneous appearance of the backbone double bond (cis/trans) signals at 5.99 and $5.25 \mathrm{ppm}$ indicated full conversion of the monomers to the polymers (Figure 5). The spectra of both block copolymers $\mathbf{9}$ and $\mathbf{1 0}$ displayed characteristic features of each monomer residue. For example, the methylene groups in the phosphonate were seen between 4.33 and $3.96 \mathrm{ppm}$, while the methyl protons in N-(butyl)-cis-5norbornene-exo-2,3-dicarboximide 4 resonated between 1.03 and $0.87 \mathrm{ppm}$. The backbone protons arising from the norbornene imide unit of the monomers overlap. The composition of the block copolymers was determined via ${ }^{1} \mathrm{H}$ NMR spectroscopy by comparing the integrals of the methylene proton resonances in the phosphonate ester functionality with those of the backbone double bonds. The experimentally determined values were very close to the theoretical ones (Table 1). These results indicated the successful block copolymerization of monomers $\mathbf{1}$ and $\mathbf{4}$, which was independent of the order of monomer addition. Two distinct $\mathrm{T}_{\mathrm{g}}$ at $75^{\circ} \mathrm{C}$ for the 
A)
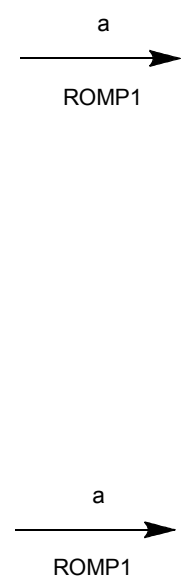

B)
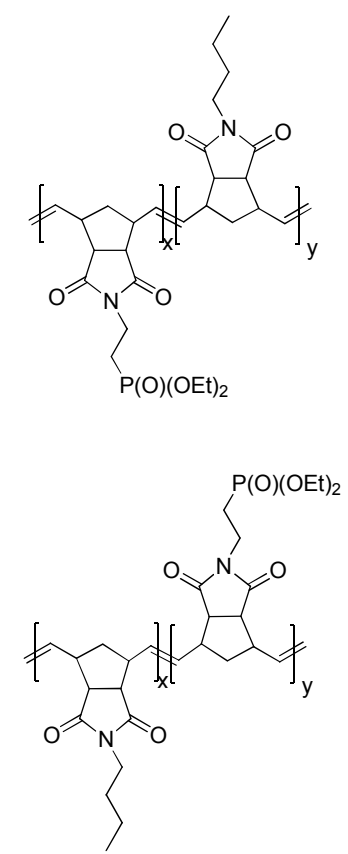
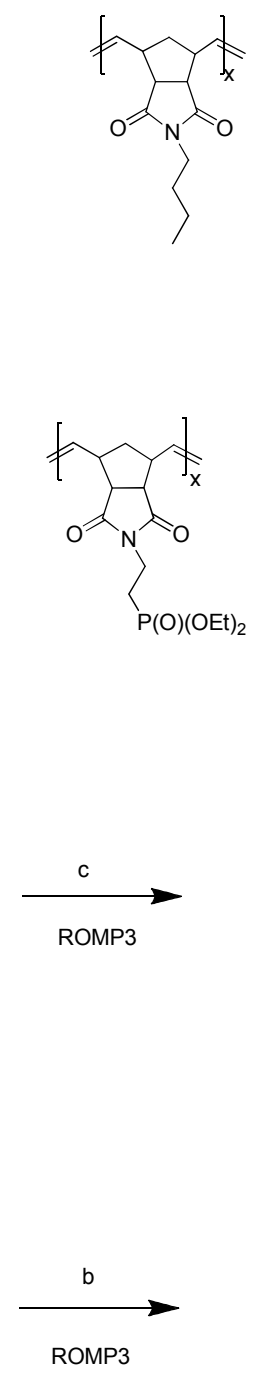
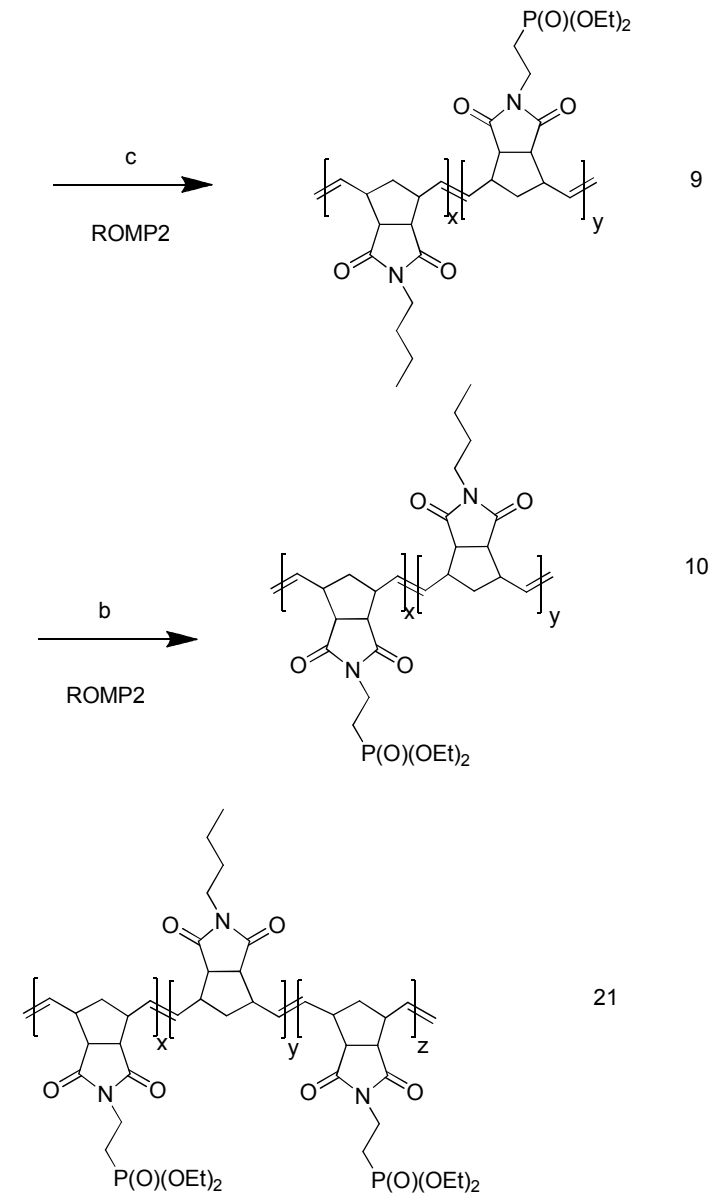

21

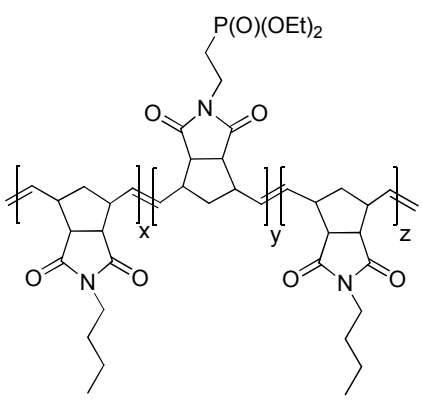

Scheme 3. Synthetic route to a) diblock (b) triblock phosphonated poly(norbornene imide)s. Reagents and conditions: (a) $\mathrm{CH}_{2} \mathrm{Cl}_{2}, \mathbf{3}$, room temperature (b) i. 4, $\mathrm{CH}_{2} \mathrm{Cl}_{2}$ ii. ethyl vinyl ether (c) i. 1, $\mathrm{CH}_{2} \mathrm{Cl}_{2}$ ii. ethyl vinyl ether. 


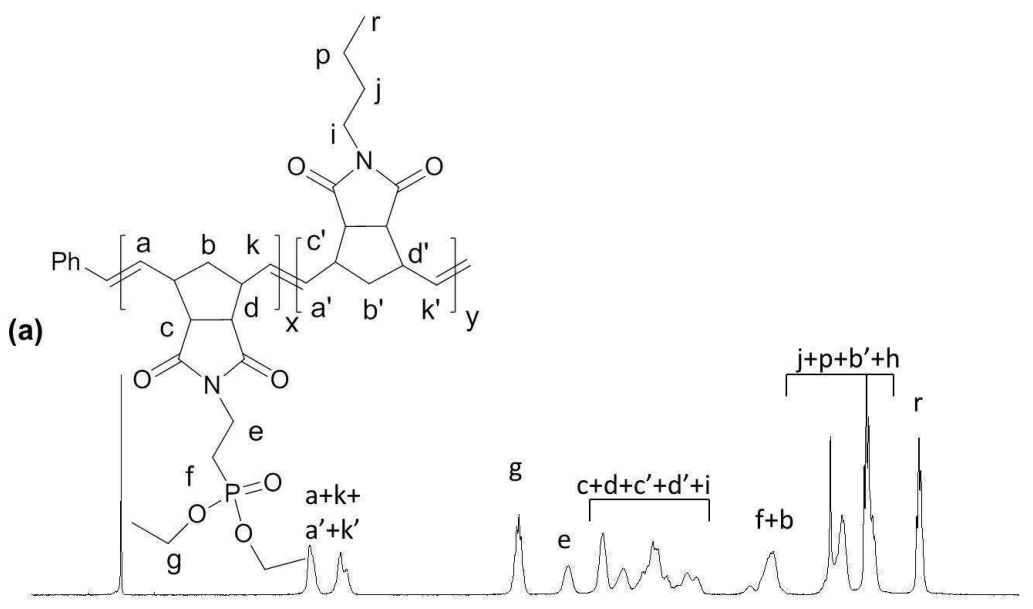

(b)
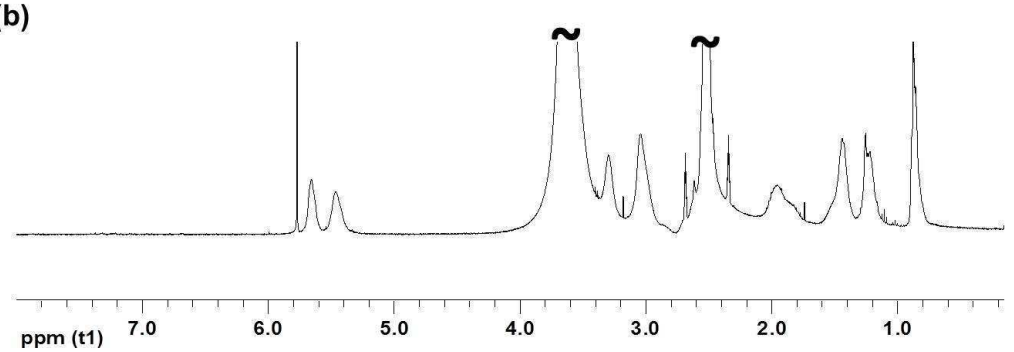

(c)

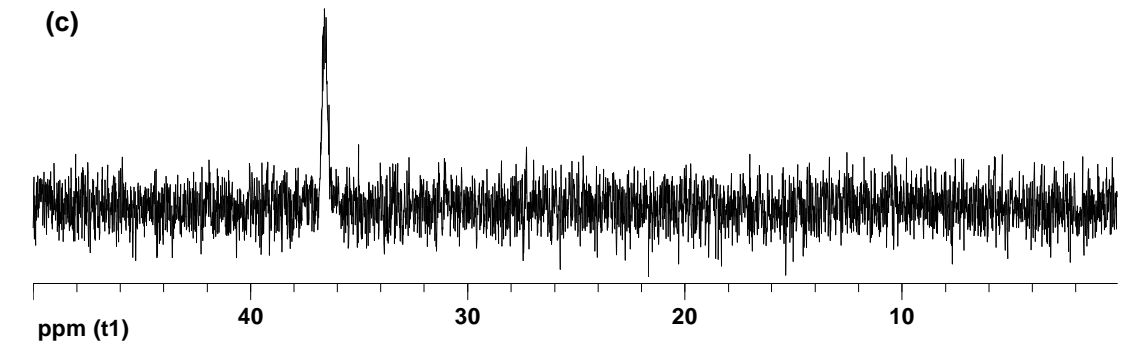

(d)

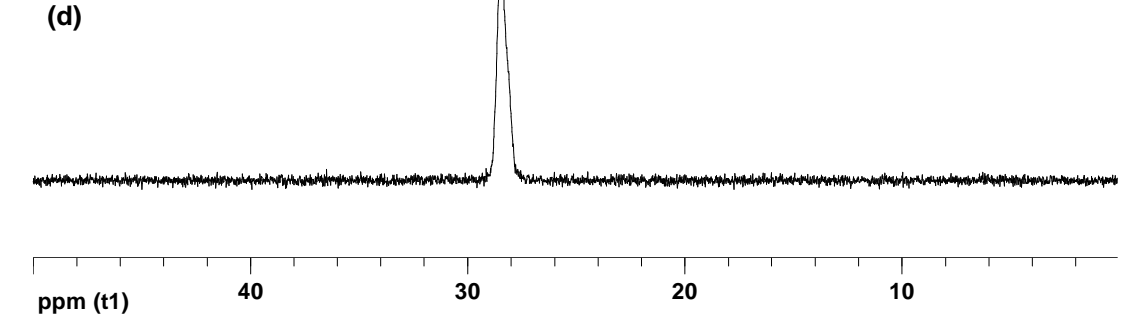

Fig. 5. ${ }^{1} \mathrm{H}$ NMR spectra of diblock copolymer (a) 9 in $\mathrm{CDCl}_{3}$ (b) 17 in $\mathrm{d}_{6}$-dimethyl sulfoxide, respectively, and ${ }^{31} \mathrm{P}$ NMR spectra of (c) 9 in $\mathrm{d}_{6}$-dimethyl sulfoxide (d) 17 in $\mathrm{d}_{6}$-dimethyl sulfoxide, respectively. 
phosphonated block and $115{ }^{\circ} \mathrm{C}$ for the non-phosphonated block were observed in the DSC traces for both diblock copolymer $\mathbf{9}$ and $\mathbf{1 0}$ (Figure 4). For comparison, we also recorded the DSC trace of poly(norbornene N-butyl imide) homopolymer 20. These findings provide an additional evidence for the successful block copolymerization. ROMP is more advantageous than the rare earth metal mediated polymerization because of its ability to yield block copolymers from phosphonated and non-phosphonated monomers with controlled molecular weight and composition, independent on the order of monomer addition.

Exploiting the unique ability of ROMP to polymerize phosphonated and nonphosphonated monomers independent on the order of the monomer addition, we prepared triblock copolymers with phosphonated segments either at the chain ends (21) or in the midchain (22) by sequential ROMP from phosphonated norbornene imide $\mathbf{1}$ and $\mathrm{N}$-(butyl)-cis-5norbornene-exo-2,3-dicarboximide 4 under nitrogen on the benchtop in $\mathrm{CH}_{2} \mathrm{Cl}_{2}$ (Scheme $3 b$ ). The complete disappearance of the characteristic monomer olefin protons (at $6.26 \mathrm{ppm}$ for $\mathbf{1}$, and $6.30 \mathrm{ppm}$ for 4), and the simultaneous appearance of the backbone double bond (cis/trans) signals at 5.78 and $5.53 \mathrm{ppm}$ indicated full conversion of the monomers to the polymers (Figure 6a). The ${ }^{1} \mathrm{H}$ NMR spectra of triblock copolymers in their ester form (21 and $\mathbf{2 2}$ ) contain the same features as that of diblock copolymers (9 and 10). The polymer composition determined from ${ }^{1} \mathrm{H}$ NMR spectrum as described for the diblock copolymer case is very similar to feed composition (Table 1). Analysis of molecular weight and molecular weight distribution of the triblock copolymers using SEC as well as SEC-MALLS indicated that triblock copolymers have low polydispersity and molar masses depending on the monomer-to-catalyst ratio (Table 1). In addition, to confirm triblock copolymerization, we took a sample from the polymerization medium before adding the monomers to make the third segment, and analysed the molecular 


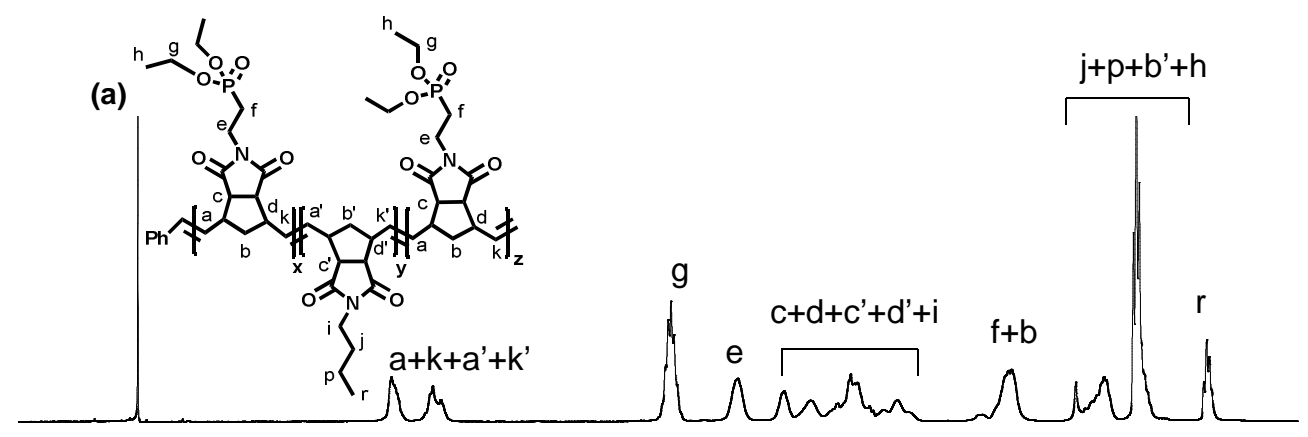

(b)

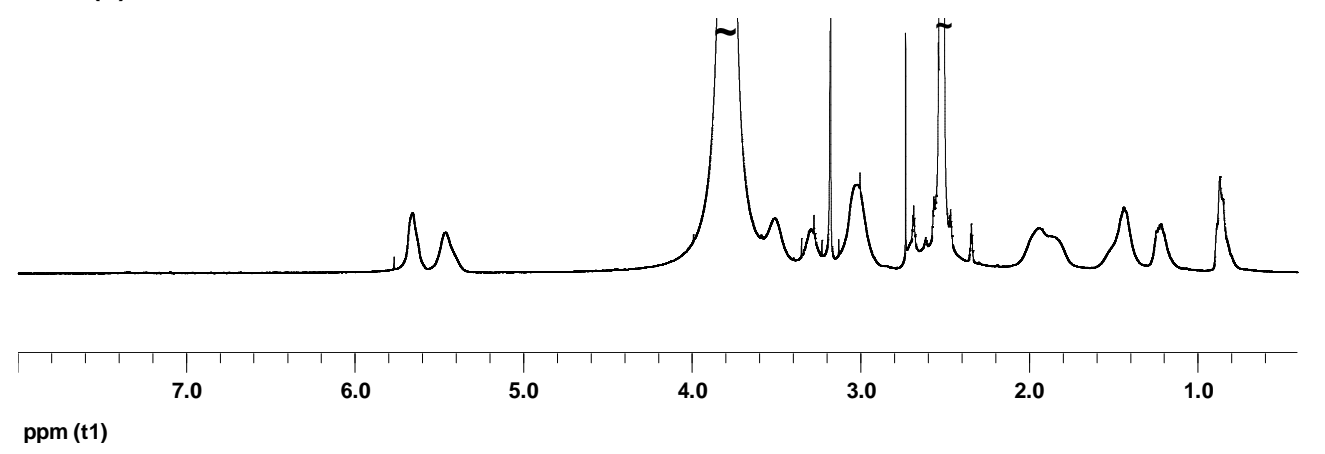

(c)

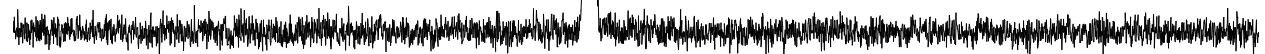

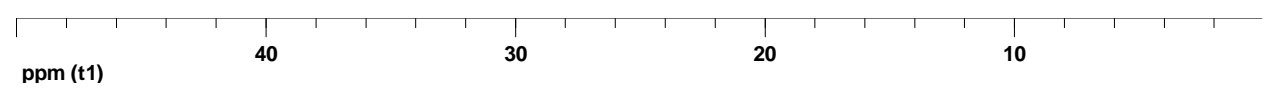

(d)

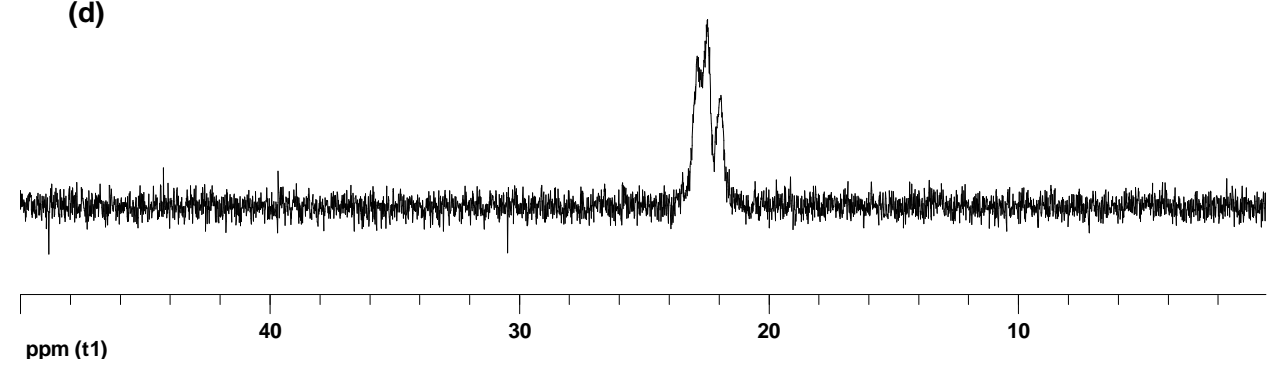

Fig. 6. ${ }^{1} \mathrm{H}$ NMR spectra of triblock copolymer (a) 21 in $\mathrm{CDCl}_{3}$ (b) 23 in $\mathrm{d}_{6}$-dimethyl sulfoxide, respectively, and ${ }^{31} \mathrm{P}$ NMR spectra of (c) 21 in $\mathrm{CDCl}_{3}$ (d) 23 in $\mathrm{d}_{6}$-dimethyl sulfoxide, respectively. 
weight and molecular weight distribution of this sample. Comparing the molecular weight of the sample taken before addition of the monomers for the third block and triblock copolymer indicated an increase of the molecular weight (Table 1 and Table S1). DSC traces of triblock copolymers (21 and 22) contain only the $T_{g}$ of the phosphonated segment. These results indicate that the success of ROMP in yielding triblock copolymers with pre-determined molecular weight in addition to low polydispersity. Such triblock copolymers bearing phosphonated sites either in the mid-chain or at the chain end remained up to now inaccessible via other polymerization techniques such as rare-earth mediated polymerization.

\subsection{Hydrolysis}

Phosphonic acid functional polymers were obtained by treating the phosphonated polymers with trimethylsilyl bromide in dry $\mathrm{CH}_{2} \mathrm{Cl}_{2}$ overnight at $32{ }^{\circ} \mathrm{C}$ to yield trimethylsilyl esters, which were then cleaved in a mixture of $\mathrm{CH}_{2} \mathrm{Cl}_{2}$ and methanol (Scheme 4). Complete hydrolysis of ester groups was confirmed by ${ }^{1} \mathrm{H}$ NMR spectroscopy. The signals from methylene and methyl protons of the phosphonate functionality are absent in the ${ }^{1} \mathrm{H}$ NMR spectra of the homopolymer (15) (Figure 2). ${ }^{1}$ H NMR spectra of homopolymer (16), diblock (17) and triblock copolymers after hydrolysis (23-24) did not contain any signals arising from the methylene protons in the phosphonate ester group (Figure 3, 5, 6). In addition, a decrease in the integration was observed between 1-2 ppm due to the loss of methyl protons in the ester group. The resonance due to the phosphonic acid moiety was observed at a higher field than that of

phosphonate ester in the ${ }^{31} \mathrm{P}$ NMR spectra of polymers. Also, the bandwidth of the resonances of the phosphonic acid functional polymers was broader than their phosphonated counterparts. This may be due to hydrogen bonding and/or aggregation processes. No $\mathrm{T}_{\mathrm{g}}$ was detected by DSC analysis of the phosphonic acid derivatives. This may be due to the formation of the 
intermolecular anhydride bonds above $100{ }^{\circ} \mathrm{C}$, which would obscure any glass transition by the broad endothermic contribution of the water evaporation. This has been previously observed with various polymers containing phosphonic and carboxylic acid groups [35].
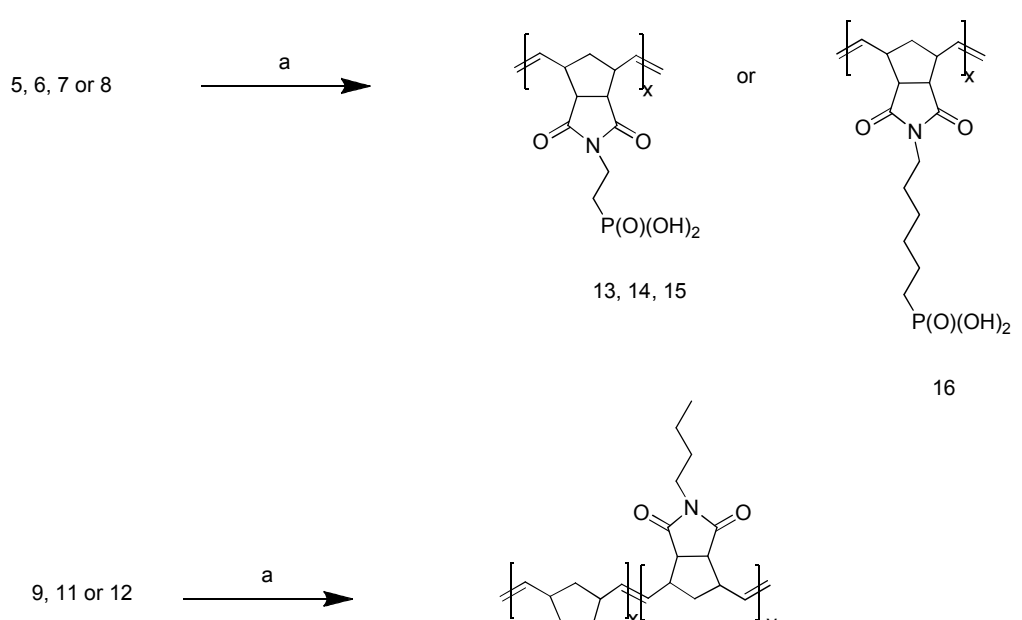

9,11 or 12

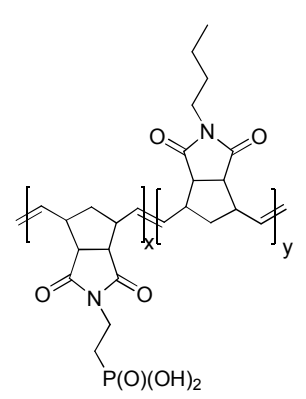

16

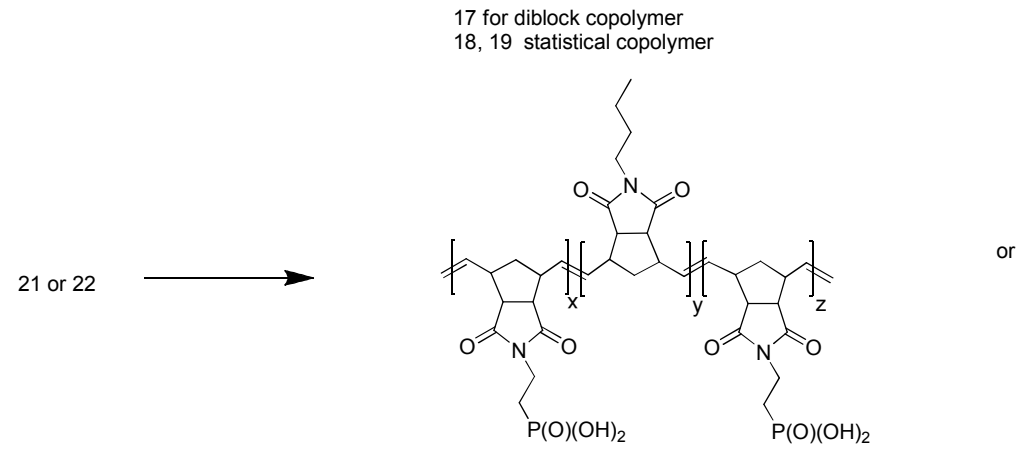

23

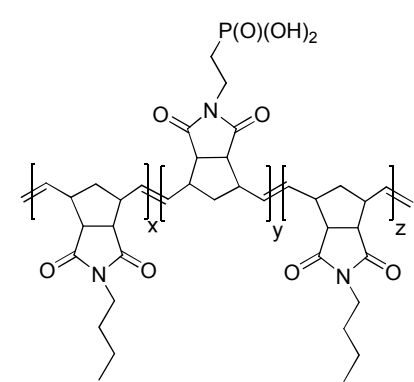

24

Scheme 4. Hydrolysis of phosphonated poly(norbornene imide)s. Reagents and conditions: (a)

\subsection{Basic Polymer Properties}

Polymer Solubility. The solubility of the polymers was investigated since it is an important parameter for both analysis and processing of polymers (Table S2). In the ester form, the homopolymers and copolymers showed a good solubility $(\sim 5 \mathrm{wt} / \mathrm{v}$ percent $)$ in various 
organic solvents irrespective of their molecular weight, composition, and architecture. The solubility properties of the polymers changed drastically after hydrolysis. All phosphonic acid functional polymers homopolymers, diblock and statistical copolymers displayed good solubility in dimethyl sulfoxide ( $\sim \mathrm{wt} / \mathrm{v}$ percent). However, the solubility of phosphonic acid functional polymers in other organic solvents decreased due to the presence of the hydrophilic and hydrogen bonding phosphonic acid groups. High molecular weight phosphonic acid functional homopolymers with both short and long alkyl side chains were insoluble in organic solvents other than dimethyl sulfoxide. Lower molecular weight homopolymers obtained from the short alkyl side chain monomers dissolved also in N-methyl pyrrolidone. Although the hydrolysis increased the hydrophilicity of the polymers, this was is insufficient to make the polymers water soluble in most cases. Low molecular weight phosphonic acid functional homopolymers with short side chains $(\mathrm{n}=2) \mathbf{1 3}$ and $\mathbf{1 4}$ dissolved to a small extent ( 0.1 wt/v percent) in water, while the higher molecular weight sample $\mathbf{1 5}$ was insoluble in water at room temperatures and above. The high molecular weight phosphonic acid homopolymer $\mathbf{1 6}$ obtained from the phosphonated norbornene imide with long side chain monomer 2 was insoluble in water. The low solubility of phosphonic acid functional poly(norbornene imide)s is most probably due to the hydrophobic nature of the polymer backbone.

Phosphonic acid functional copolymers 17-19 displayed a higher solubility in organic solvents than their homopolymer counterparts. Diblock copolymer $\mathbf{1 7}$ in the acid form were soluble in in $\mathrm{N}, \mathrm{N}$-dimethyl formamide, whereas phosphonic acid functional homopolymers 1315 obtained from the same monomer was insoluble in this solvent at the same concentration. Hydrolyzed statistical copolymers 18-19 with both low and high degree of polymerization dissolved in N-methyl pyrrolidone. Morover, the low molecular weight polymer $\mathbf{1 8}$ was also 
soluble in N,N-dimethyl formamide. Triblock copolymer with outer hydrophobic segments and inner phosphonated segment (24) in the acid form dissolves in $\mathrm{N}, \mathrm{N}$-dimethyl formamide, $\mathrm{N}$ methyl pyrrolidone, dimethyl sulfoxide and dimethyl acetamide while the triblock copolymer with outer hydrophilic segments and inner hydrophobic segment (23) is soluble in N-methyl pyrrolidone, dimethyl sulfoxide and dimethyl acetamide. Among the copolymers, only the phosphonic acid functional statistical copolymer with the lower degree of polymerization $\mathbf{1 8}$ dissolved in water $(<0.1 \mathrm{wt} / \mathrm{v}$ percent $)$. These findings indicated that variations of the alkyl chain length, and the molecular weight, as well as the monomer composition by copolymerization, are useful parameters to tune the solubility of phosphonic acid functional poly(norbornene imides). The water soluble polymers 18-19 did not show any cloud point between 20 and $95^{\circ} \mathrm{C}$.

Thermal Stability of the Polymers. All phosphonated and phosphonic acid functional poly(norbornene imide)s are thermally stable up to high temperatures under both nitrogen and air atmosphere (Figure 7-8). For the phosphonic acid polymers, a slow weight loss was observed above $160{ }^{\circ} \mathrm{C}$ under nitrogen, which was due to the formation of phosphonic acid anhydrides by loss of water. It is worth to note that the polymers in the ester form also lost weight above $150{ }^{\circ} \mathrm{C}$. The weight loss was highest for the triblock copolymer (22). All phosphonated poly(norborne imide)s in the ester form degraded in two steps under nitrogen atmosphere. The first step occurred between 300 and $330{ }^{\circ} \mathrm{C}$ for all phosphonated polymers, and is due to the degradation of the phosphonates by the formation and loss of ethylene. The weight loss was highest for the phosphonated polymer with the highest phosphonic acid content, and decreased with the phosphonic acid content. The observed weight loss and theoretical weight loss calculated based on the polymer composition are in good agreement (Table S3). The second degradation step occured between 323 and $500{ }^{\circ} \mathrm{C}$. It was mainly due to the $\mathrm{C}$-P bond cleavage 


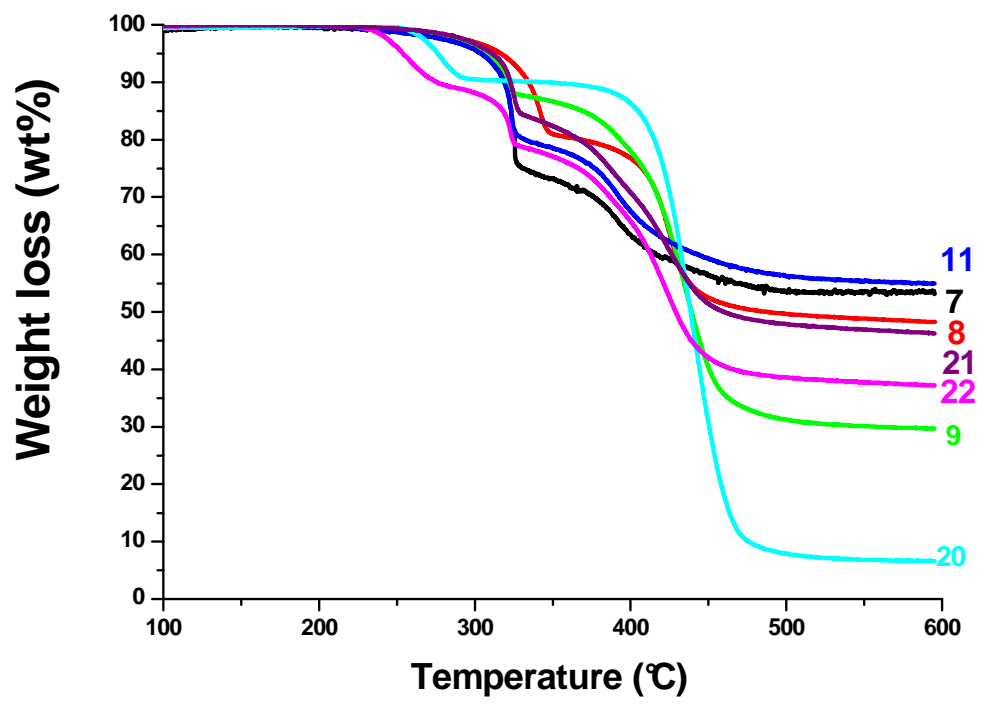

Fig. 7. TGA traces polymers recorded at $10{ }^{\circ} \mathrm{C} / \mathrm{min}$ under nitrogen atmosphere.

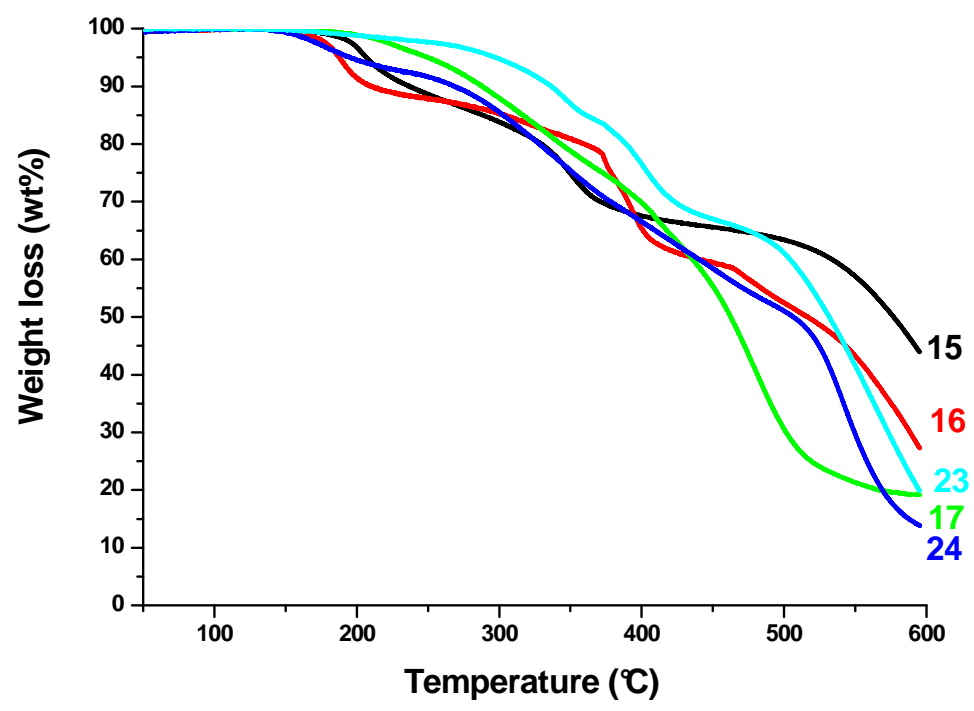

Fig. 8. The TGA traces polymers recorded at $1{ }^{\circ} \mathrm{C} / \mathrm{min}$ in air.

in polymers. In the case of the copolymers, there might be also contribution from the degradation of the norbornene $\mathrm{N}$-butyl imide segment since poly(norbornene $\mathrm{N}$-butyl imide) had a 
degradation step between 398 and $476{ }^{\circ} \mathrm{C}$. The thermal stability of all the phosphonated polymers decreased under air when compared to nitrogen atmosphere. Under air, the first degradation step was observed between 240 and $284{ }^{\circ} \mathrm{C}$, while the second degradation step started at $289{ }^{\circ} \mathrm{C}$ and continued to $600{ }^{\circ} \mathrm{C}$ until complete degradation. The degradation events observed under air were the same as described for the degradation under nitrogen.

Film Formation. We investigated the film forming properties of high molecular weight phosphonated homopolymers and block copolymers. Transparent films were obtained upon casting from dilute solutions of the phosphonated poly(norbornene imide)s in chloroform followed by drying. The resulting films were very sticky and could not be detached without damage. Transparent, free standing, and mechanically stable films were obtained from a dilute solution of the phosphonic acid functional homopolymer $\mathbf{1 6}$ with long alkyl chain $(n=6)$ in dimethyl sulfoxide. A transparent film was formed upon casting the phosphonic acid functional homopolymer 15 with the short alkyl chains $(n=2)$ under the same conditions. However, this film could not be detached from the glass substrate without damage. The higher mechanical stability of the films obtained from the phosphonic acid functional poly(norbornene imide)s with longer alkyl chain may be related to the lower density of phosphonic acid group in these polymers. Block copolymerization of monomer 1 with 4 improved the mechanical stability of the films. Transparent, free standing and mechanically stable phosphonic acid functional membranes were obtained upon casting films from dilute solutions of this block copolymer $\mathbf{1 7}$ in $\mathrm{N}, \mathrm{N}$-dimethyl formamide (Figure S1). Casting from dilute solutions of triblock copolymer (24) in dimethyl sulfoxide yielded transparent, free standing and mechanically stable films. The thickness of the films ranged from 70 to $100 \mu \mathrm{m}$. As a first step to characterize the phosphonated polymer films, water uptake was determined gravimetrically as function of temperature between 20 and $100{ }^{\circ} \mathrm{C}$, 
and the results were correlated with the ion-exchange capacity of the samples (Table 2). The films obtained from the phosphonic acid functional homopolymer (16) with an ion exchange capacity of $3.05 \mathrm{mmol}$ phosphorous/g took up $43 \mathrm{wt} \%$ water at $20{ }^{\circ} \mathrm{C}$, and the water uptake did increase only very little upon increasing the temperature to $100{ }^{\circ} \mathrm{C}$. The film prepared from phosphonic acid functional diblock copolymer (17), which has a lower ion exchange capacity than that of the homopolymer (16) absorbed $19 \mathrm{wt} \%$ water at room temperature, and the water uptake reached to the same value $(40 \mathrm{wt} \%)$ as the homopolymer (16) at $100{ }^{\circ} \mathrm{C}$. Similar observations are valid for the film prepared from triblock copolymer with outer hydrophobic blocks and inner hydrophilic block. The differences in the water uptake characteristics of the films may reflect variations in their morphology. These results indicate that polymer architecture is a useful parameter to tune the water-uptake behaviour of the phosphonated films. Detailed investigations on understanding how molecular properties of the polymers such as composition and architecture affect morphology and water uptake is the topic of future work.

\section{Table 2}

Ion exchange capacity and water uptake of phosphonic acid functional films.

\begin{tabular}{llll}
\hline Entry & Ion exchange capacity (mmol phosphorous/g) & Water uptake at $20^{\circ} \mathrm{C}$ (weight \%) & Water uptake at $100^{\circ} \mathrm{C}($ weight \%) \\
\hline Homopolymer 16 & 3.05 & 43 & 49 \\
Diblock copolymer $\mathbf{1 7}$ & 1.2 & 19 & 48 \\
Triblock copolymer $\mathbf{2 4}$ & 1.7 & 13 & 34 \\
\hline
\end{tabular}

\section{Conclusions}

For the first time, phosphonated homopolymers as well as statistical, diblock and triblock copolymers with controlled molecular weight, composition, and architecture were readily obtained via ROMP of phosphonated norbornene imides at room temperature. The phosphonic esters were hydrolyzed under mild conditions to quantitatively yield the phosphonic acid 
derivatives. The synthetic results highlight the unique features of ROMP for synthesis of phosphonated polymers compared to anionic, controlled radical and rare-earth metal mediated polymerizations. The resulting polymers have high thermal and thermo-oxidative stability both in ester and acid form, and were stable up $240{ }^{\circ} \mathrm{C}$ and $160{ }^{\circ} \mathrm{C}$, respectively. In addition, they show good film forming properties. Combining these basic properties with the synthetic advantages mentioned above make ROMP a promising pathway for accessing phosphonated macromolecular structures with higher complexity directly from phosphonated monomers, and allow fine-tuning of material properties in a straightforward manner.

\section{Acknowledgment}

This work was funded by the European Community's Seventh Framework Programme (FP7/2010-2013) under the call ENERGY-2010-10.2-1: Future Emerging Technologies for Energy Applications (FET) under contract 256821 QuasiDry. We acknowledge help of Christine Rosenauer for her technical assistance in molecular weight determination.

\section{Appendix A. Supplementary data}

Supplementary data related to this article is available online free of charge.

\section{References}

[1] Zeller A, Musyanovych A, Kappl M, Ethirajan A, Dass M, Markova D, Klapper M, Landfester K. Nanostructured Coatings by Adhesion of Phosphonated Polystyrene Particles onto Titanium Surface for Implant Material Applications. ACS Appl Mater Inter 2010; 2: 2421.

[2] Anbar M, Farley EP. Potential use of organic polyphosphonates as adhesives in restoration of teeth. J Dent Res 1974; 53: 879.

[3] Alexandratos SD, Natesan S. Ion-selective polymer-supported reagents: the principle of bifunctionality. Eur Polym J 1999; 35: 431-436 
[4] Kaltbeitzel A, Schauff S, Steininger H, Bingöl B, Brunklaus G, Meyer WH, Spiess HW. Water sorption of poly(vinylphosphonic acid) and its influence on proton conductivity. Solid State Ionics 2007; 178: 469-474.

[5] Steininger H, Schuster M, Kreuer KD, Kaltbeitzel A, Bingöl B, Schauff S, Brunklaus G, Meyer WH, Maier J, Spieß HW. Intermediate temperature proton conductors for PEM fuel cells based on phosphonic acid as protogenic group: A progress report. Phys Chem Chem Phys 2007; 9: 1764-1773.

[6] Perrin R, Elomaa M, Jannasch P. Nanostructured proton conducting polystyrenepoly(vinylphosphonic acid) block copolymers prepared via sequential anionic polymerizations. Macromol 2009; 42: 5146-5154.

[7] Bingöl B, Meyer WH, Wagner M, Wegner G. Synthesis, microstructure, and acidity of poly (vinylphosphonic acid). Macromol Rapid Commun 2006; 27: 1719-1724.

[8] Wagner T, Manhart A, Deniz N, Kaltbeitzel A, Wagner M, Brunklaus G, Meyer WH. Vinylphosphonic Acid Homo- and Block Copolymers. Macromol Chem Phys 2009; 210: 19031914.

[9] Blidi I, Geagea R, Coutelier O, Mazieres S, Violleau F, Destarac M, Aqueous RAFT/MADIX polymerisation of vinylphosphonic acid. Polym Chem 2012; 3: 609612.

[10] Bingöl B, Hart-Smith G, Barner-Kowollik C, Wegner G. Characterization of oligo(vinyl phosphonate)s by high-resolution electrospray ionization mass spectrometry: Implications for the mechanism of polymerization. Macromol 2008; 41: 1634-1639.

[11] Ingratta $\mathrm{M}$, Elomaa $\mathrm{M}$, Jannasch, P. Grafting poly(phenylene oxide) with poly(vinylphosphonic acid) for fuel cell membranes. Polym Chem 2010; 1: 739-746.

[12] Parvole J, Jannasch P. Polysulfones grafted with poly(vinylphosphonic acid) for highly proton conducting fuel cell membranes in the hydrated and nominally dry state. Macromol 2008; 41: 3893-3903.

[13] Shaplov AS, Lozinskaya EI, Odinets IL, Lyssenko KA; Kurtova SA, Timofeeva, GI, Iojoiu C, Sanchez, J.-Y, Abadie MJM, Yu. Voytekunas V, Vygodskii YS. Novel phosphonated poly(1,3,4-oxadiazole)s: Synthesis in ionic liquid and characterization. React Funct Polym 2008; 68: 208-224.

[14] Yamabe M, Akiyama K, Akatsuka Y, Kato M. Novel phosphonated perfluorocarbon polymers. Eur Polym J 2000; 36: 1035-1041.

[15) Çelik SÜ, Akbey Ü, Graf R, Bozkurt A, Spiess HW. Anhydrous proton-conducting properties of triazole-phosphonic acid copolymers: a combined study with MAS NMR. Phys Chem Chem Phys 2008; 10: 6058-6066.

[16] Bozkurt A, Meyer WH, Gutman, J, Wegner, G. Proton conducting copolymers on the basis of vinylphosphonic acid and 4-vinylimidazole. Solid State Ionics 2003; 164: 169-173.

[17] Bingöl B, Strandberg C, Szabo A, egner G. Copolymers and hydrogels based on vinylphosphonic acid. Macromol 2008; 41: 2785-2790.

[18] Jin S, Gonsalves KE. Synthesis and characterization of functionalized poly(epsiloncaprolactone) copolymers by free-radical polymerization. Macromol 1998; 31: 1010-1015.

[19] Millaruelo M, Steinert V, Komber H, Klopsch R, Voit B. Synthesis of vinylphosphonic acid anhydrides and their copolymerization with vinylphosphonic acid. Macromol Chem Phys 2008; 209: 366-374.

[20] Jiang F, Kaltbeitzel, A, Fassbender B, Brunklaus G, Pu H, Meyer WH, Spiess HW, Wegner G. Effect of Polymer Composition and Water Content on Proton Conductivity in Vinyl 
Benzyl Phosphonic Acid-4-Vinyl Pyridine Copolymers. Macromol Chem Phys 2008; 209: 24942503.

[21] Markova D, Kumar A, Klapper M, Müllen K. Phosphonic acid-containing homo-, AB and BAB block copolymers via ATRP designed for fuel cell applications. Polymer 2009; 50: 3411-3421.

[22] Seemann UB, Dengler JE, Rieger B. High-molecular-weight poly(vinylphosphonate)s by single-component living polymerization initiated by rare-earth-metal complexes. Angew Chem Int Ed 2010; 49: 3489-3491.

[23] Rabe GW, Komber H, Haussler L, Kreger K, Lattermann G. Polymerization of diethyl vinylphosphonate mediated by rare-earth tris(amide). Macromol 2010; 43: 1178-1181.

[24] Salzinger S, Rieger B. Rare earth metal-mediated group transfer polymerization of vinylphosphonates. Macromol Rapid Commun 2012; 33: 1327-1345.

[25] Bielawski CW, Grubbs RH. Living ring-opening metathesis polymerization. Prog Polym Sci $2007 ; 32: 1-29$.

[26] Eren T, Tew GN. Phosphonic acid-based amphiphilic diblock copolymers derived from ROMP. J Polym Sci Polym Chem 2009; 47: 3949-3956.

[27] Rao NV, Kishore A, Sarkar S, Sarmas JD. Norbornene-derived poly-D-lysine copolymers as quantum dot carriers for neuron growth. Biomacromol 2012; 13: 2933-2944.

[28] Marsico F, Wagner M, Landfester K, Wurm F. Unsaturated polyphosphoesters via acyclic diene metathesis polymerization. Macromol 2012; 445: 8511-8518.

[29] Montero De Espinosa L, Ronda JC, Galia M, Cadiz V, Meier MAR. Fatty acid derived phosphorus-containing polyesters via acyclic diene metathesis polymerization. J Appl Polym Sci. 2009; 47: 5760-5771.

[30] Opper KL, Markova D, Klapper M, Müllen K, Wagener KB. Precision phosphonic acid functionalized polyolefin architectures. Macromol 2010; 43: 3690-3698.

[31] Love JA, Morgan JP, Trnka TM, Grubbs RH. A practical and highly active rutheniumbased catalyst that effects the cross metathesis of acrylonitrile. Angew Chem Int Ed 2002; 41: 4037.

[32] Rosowsky A, Forsch RA, Moran RG, Kohler W, Freisheims JH. Methoxtrexate analogs: 32. Chain extention, alpha-carbonyl deletion, and gamma-carboxyl replacement by sulfonate ans phosphonate - Effect on enzyme binding and cell growth inhibition. J Med Chem 1988; 31: 1326-1331.

[33] Matson JB, Grubbs RH. ROMP-ATRP block copolymers prepared from monotelechelic poly(oxa)norbomenes using a difunctional terminating agent. Macromol 2008; 41: 5626-5631.

[34] Taffa, DH, Kathiresan M, Walder, L. Tuning the hydrophilic, hydrophobic, and ion exchange properties of mesoporous $\mathrm{TiO}_{2}$. Langmuir 2009; 25: 5371-5379.

[35] Stubenrauch K, Fritz-Popovski G, Ingolic E, Grogger W, Glatter O, Stelzer F, Trimmel G. Microphase separation study of amphiphilic ROMP block copolymers by SAXS and TEM. Macromol 2007; 40: 4592-4600. 


\title{
Supporting Information
}

\section{Well-defined Phosphonated Homo- and Copolymers via Direct Ring Opening Metathesis Polymerization}

\author{
Bahar Bingöl, ${ }^{\mathrm{a} *}$ Anja Kroeger, ${ }^{\mathrm{b}}$ Patric Jannasch ${ }^{\mathrm{a} *}$ \\ ${ }^{a}$ Department of Chemistry, Polymer and Materials Chemistry, Lund University, P.O.B. 124, SE \\ 22100 Lund, Sweden. \\ ${ }^{\mathrm{b}}$ Max Planck Institute for Polymer Research, Ackermannweg 10, D-2128 Mainz, Germany. \\ * Corresponding Authors. \\ Bahar Bingol \\ Department of Chemistry, Polymer and Materials Chemistry, Lund University, P.O.B. 124, SE \\ 22100 Lund, Sweden. Tel: (+46) 462228279 Fax: (+46) 462224012 E-mail: \\ bahar.bingol@chem.lu.se \\ Patric Jannasch \\ Department of Chemistry, Polymer and Materials Chemistry, Lund University, P.O.B. 124, SE \\ 22100 Lund, Sweden. Tel: (+46) 462229860 Fax: (+46) 462224012 E-mail: \\ patric.jannasch@chem.lu.se
}




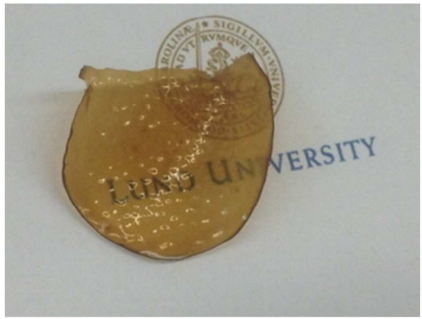

a

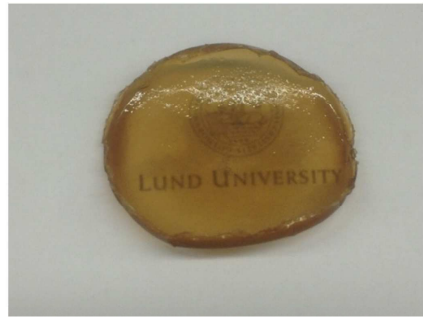

b

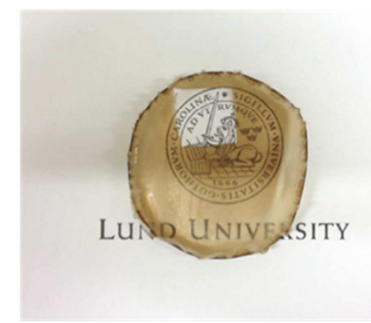

C

Fig.S1. Photographs of phosphonic acid functional membrane from (a) homopolymer 16 (b) diblock copolymer 17 and (c) triblock copolymer 24.

\section{Table S1}

Molecular characteristics of the diblock copolymers used to prepare triblock copolymers (21-22)

\begin{tabular}{lllll}
\hline $\begin{array}{l}\text { Sample used in } \\
\text { preparation of }\end{array}$ & $\mathrm{M}_{\mathrm{n}}{ }^{\mathrm{a}}(\mathrm{g} / \mathrm{mol})$ & $\begin{array}{l}\mathrm{M}_{\mathrm{w}}{ }^{\mathrm{a}} \\
(\mathrm{g} / \mathrm{mol})\end{array}$ & $\begin{array}{l}\mathrm{M}_{\mathrm{w} \text { targetted }} \\
(\mathrm{g} / \mathrm{mol})\end{array}$ & $\mathrm{PDI}^{\mathrm{a}}$ \\
\hline $\mathbf{2 2}$ & 52500 & 71500 & 62619 & 1.36 \\
$\mathbf{2 1}$ & 61512 & 76512 & 60293 & 1.24 \\
\hline
\end{tabular}

${ }^{\mathrm{a}}$ PDI: = polydispersity index determined by size exclusion chromatography, ${ }^{\mathrm{b}}$ determined using conventional multi-angle laser light scattering. 
Table S2

Polymer Solubility.

\begin{tabular}{|c|c|c|c|c|c|c|c|c|c|}
\hline Entry & Toluene & THF & $\mathrm{CH}_{2} \mathrm{Cl}_{2}$ & $\mathrm{CHCl}_{3}$ & DMF & NMP & DMAC & DMSO & $\mathrm{H}_{2} \mathrm{O}$ \\
\hline Homopolymer 7 & + & + & + & + & + & + & + & + & $\mathrm{X}$ \\
\hline Homopolymer 15 & $\mathrm{X}$ & $\mathrm{X}$ & NT & NT & $\mathrm{X}$ & $\mathrm{X}$ & $\mathrm{X}$ & + & $\mathrm{X}$ \\
\hline Homopolymer 8 & + & + & + & + & + & + & + & + & $\mathrm{X}$ \\
\hline Homopolymer 16 & $\mathrm{X}$ & $\mathrm{X}$ & NT & NT & NT & $\mathrm{X}$ & $\mathrm{X}$ & + & $\mathrm{X}$ \\
\hline Diblock copolymer 9 & + & + & + & + & + & + & + & + & $\mathrm{X}$ \\
\hline Diblock copolymer 17 & $\mathrm{X}$ & $\mathrm{X}$ & NT & NT & $\mathrm{X}$ & NT & NT & + & $\mathrm{X}$ \\
\hline Homopolymer $\mathbf{5}$ & + & + & + & + & + & + & + & + & $\mathrm{X}$ \\
\hline Homopolymer $\mathbf{1 3}$ & NT & $\mathrm{X}$ & NT & NT & $\mathrm{X}$ & + & $\mathrm{X}$ & + & + \\
\hline Homopolymer 6 & + & + & + & + & + & + & + & + & $\mathrm{X}$ \\
\hline Homopolymer 14 & NT & $\mathrm{X}$ & $\mathrm{X}$ & NT & $\mathrm{X}$ & + & $\mathrm{X}$ & + & + \\
\hline Statistical copolymer $\mathbf{1 1}$ & + & + & + & + & + & + & + & + & $\mathrm{X}$ \\
\hline Statistical copolymer $\mathbf{1 8}$ & NT & NT & $\mathrm{X}$ & NT & + & + & + & + & + \\
\hline Statistical copolymer $\mathbf{1 2}$ & + & + & + & + & + & + & + & + & $\mathrm{X}$ \\
\hline Statistical copolymer 19 & NT & NT & NT & NT & $\mathrm{X}$ & + & + & + & $\mathrm{X}$ \\
\hline Triblock copolymer $\mathbf{2 2}$ & + & + & + & + & + & + & + & + & $\mathrm{X}$ \\
\hline Triblock copolymer $\mathbf{2 4}$ & NT & NT & NT & NT & + & + & + & + & NT \\
\hline Triblock copolymer $\mathbf{2 1}$ & + & NT & + & + & + & + & + & + & NT \\
\hline Triblock copolymer $\mathbf{2 3}$ & NT & NT & NT & NT & $\mathrm{X}$ & + & + & + & NT \\
\hline
\end{tabular}

\section{Table S3}

Experimental and theoretical weight loss of the polymers.

\begin{tabular}{lll}
\hline Sample & $\begin{array}{l}\text { Weight loss observed between } 300- \\
330^{\circ} \mathrm{C}(\mathrm{wt} \%)\end{array}$ & $\begin{array}{l}\text { Weight loss calculated based on the } \\
\text { polymer composition }(\mathrm{wt} \%)\end{array}$ \\
\hline $\mathbf{7}$ & 20.0 & 17.1 \\
$\mathbf{8}$ & 15.1 & 16.4 \\
$\mathbf{9}$ & 7.7 & 8.0 \\
$\mathbf{2 2}$ & 9.3 & 9.6 \\
$\mathbf{2 1}$ & 11.0 & 13.0 \\
$\mathbf{1 1}$ & 14.0 & 15.6 \\
\hline
\end{tabular}


Table of Content

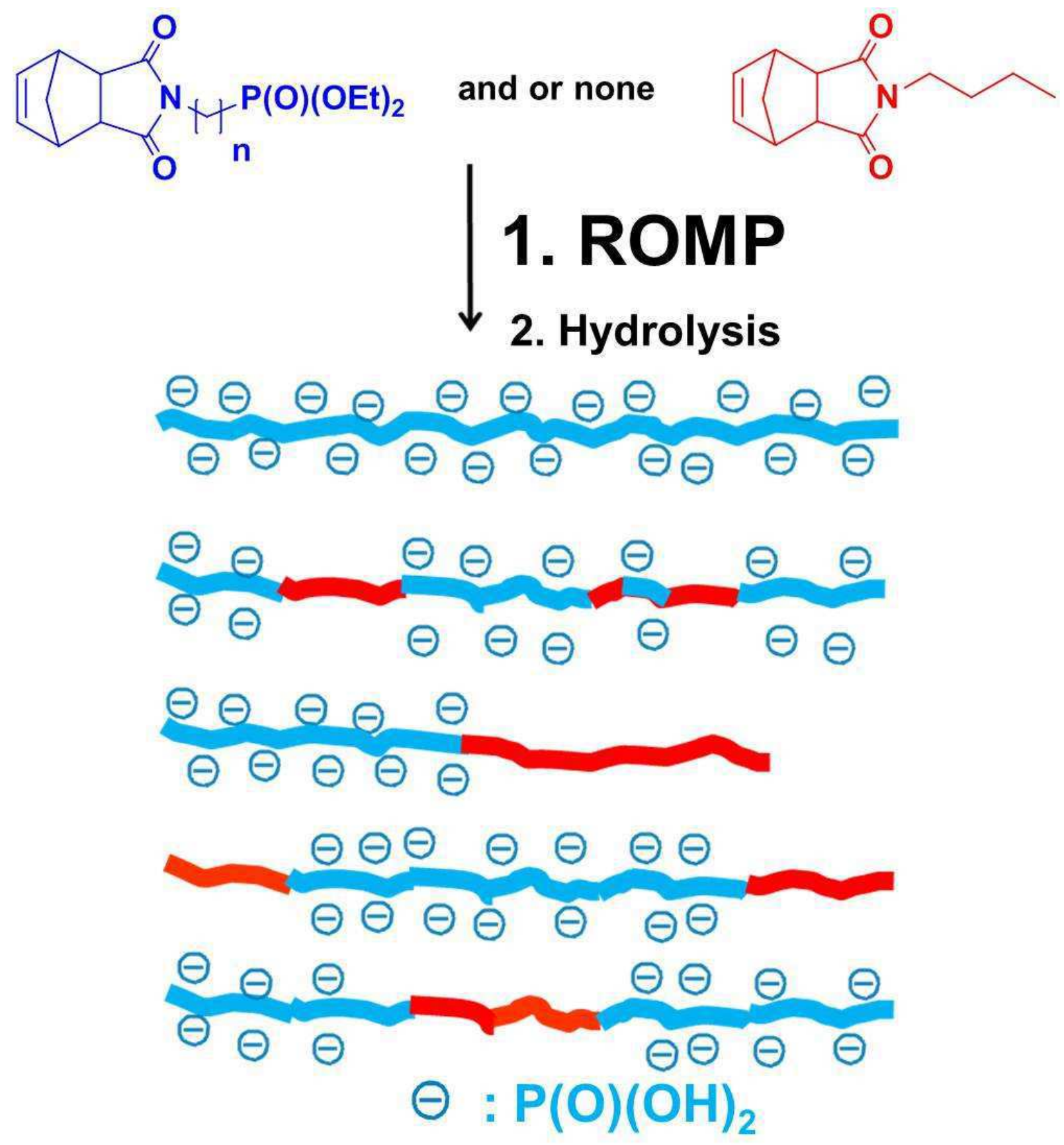

